\title{
Extrinsic neuromodulation in the rodent olfactory bulb
}

\author{
Daniela Brunert ${ }^{1} \cdot$ Markus Rothermel $^{1}[0$
}

Received: 1 October 2020 / Accepted: 24 November 2020 / Published online: 23 December 2020

(c) The Author(s) 2020

\begin{abstract}
Evolutionarily, olfaction is one of the oldest senses and pivotal for an individual's health and survival. The olfactory bulb (OB), as the first olfactory relay station in the brain, is known to heavily process sensory information. To adapt to an animal's needs, OB activity can be influenced by many factors either from within (intrinsic neuromodulation) or outside (extrinsic neuromodulation) the OB which include neurotransmitters, neuromodulators, hormones, and neuropeptides. Extrinsic sources seem to be of special importance as the OB receives massive efferent input from numerous brain centers even outweighing the sensory input from the nose. Here, we review neuromodulatory processes in the rodent OB from such extrinsic sources. We will discuss extrinsic neuromodulation according to points of origin, receptors involved, affected circuits, and changes in behavior. In the end, we give a brief outlook on potential future directions in research on neuromodulation in the OB.
\end{abstract}

Keywords Olfactory bulb $\cdot$ Neuromodulation $\cdot$ Rodents $\cdot$ Olfactory processing $\cdot$ Perception

\section{Introduction}

We live in an ever-changing environment that poses an enormous challenge to our nervous system. Granting our behavioral flexibility, the ability to perceive and act upon sensory stimuli in a differentiated way is a process called neuromodulation. Neuromodulation, defined as "the alteration of cellular or synaptic properties by a neuron or a substance released by neurons" (Katz 1999) is a topic that has received more and more attention over the last years. Formerly characterized as a form of slow and diffuse neuronal communication (Bucher and Marder 2013) is it now recognized that neuromodulation acts on multiple timescales (Nadim and Bucher 2014) and that all neuronal circuits are subject to modulatory influences (e.g., Jacob and Nienborg 2018). This modulation is easily noticeable in sensory systems where stimulus perception changes dependent on processes such as mood or attention. One of the most famous examples of such a change in perception is the "invisible gorilla experiment" (https://www. youtube.com/watch?v=vJG698U2Mvo) from Daniel Simons and Christopher Chabris who demonstrated that even large

Markus Rothermel

m.rothermel@sensorik.rwth-aachen.de

1 Department of Chemosensation, AG Neuromodulation, Institute for Biology II, RWTH Aachen University, 52074 Aachen, Germany objects can become invisible if attention is directed away from them.

While evidence for neuromodulatory processes can be found across all sensory modalities (Ferezou et al. 2006; Reynolds and Chelazzi 2004; Zelano and Sobel 2005), the exact mechanism leading to changes in behavior is oftentimes hard to pinpoint, mainly for two reasons: in the immensely complex landscape of sensory processing, there are multiple neuromodulatory mechanisms for every brain area and each of those mechanisms typically also influences multiple cellular systems.

The olfactory system offers a unique opportunity for studying mechanisms underlying neuromodulatory changes in sensory systems, especially in rodents, macrosmatic animals. A major advantage of the olfactory system is its relative simplicity since primary olfactory cortices are three-layered paleocortical structures (Wilson et al. 2014) and olfactory information can reach (neo) cortical areas without being relayed via the thalamus (Moberly et al. 2018). Additionally, behavioral responses, due to changes in hormonal or nutritional status as well as attention or experience-dependent modulation, can be easily observed.

Early sensory processing, i.e., only one or two synapses downstream of primary sensory neurons, holds a special role in olfaction. The olfactory bulb (OB), the first relay station of olfactory information in the brain, is a bulbous laminar structure located anterior to the rodent forebrain. 
In contrast to other sensory systems where early processing structures are embedded deep inside the brain, the OB is highly accessible to physiological recording techniques. Formerly thought to represent a simple information relay between sensory input and cortex, it is now recognized as a central olfactory processing hub (Cleland 2010). This processing is highly dependent on modulatory processes originating both inside ("intrinsic neuromodulation") as well as outside ("extrinsic neuromodulation") of the OB (see Lizbinski and Dacks 2017). Especially extrinsic sources seem to have a large influence on $\mathrm{OB}$ information processing as the $\mathrm{OB}$ receives massive efferent input from numerous brain centers outweighing the sensory input from the nose (Shepherd 1972).

The topic of OB neuromodulation has gained more interest over the last years with many new and interesting studies shedding light on the different mechanisms. Recent reviews give a good summary of particular modulatory mechanisms (Gaudry 2018; Harvey and Heinbockel 2018; Li et al. 2020; Lizbinski and Dacks 2017; Sayin et al. 2018) but mostly focus on just one or a few of the multiple sources for neuromodulation. Building on our previous work (Brunert and Rothermel 2019; McIntyre et al. 2017), we here aim to give a more comprehensive overview of extrinsic influencers of olfactory processing in mice. In this review, we significantly expanded the chapters on each specific neuromodulatory factor with a special focus on their sources, effectors within the $\mathrm{OB}$, changes in cellular output, and behavioral consequences. Furthermore, we give an outlook on potential future research topics and discuss a selection of open questions in the field of $\mathrm{OB}$ neuromodulation that might help to further increase interest in this challenging, but very fascinating topic.

\section{Neuroanatomy of the vertebrate olfactory bulb}

The cellular composition and synaptic connectivity of the rodent $\mathrm{OB}$ are reasonably well established (for review see Burton et al. 2020; Nagayama et al. 2014; Wachowiak and Shipley 2006), a prerequisite of understanding neuromodulatory effects. We want to briefly introduce the anatomy of the OB and mention cell types that have been shown to play a role as effectors of extrinsic neuromodulation.

The OB, as the first structure of odor processing, receives olfactory information from axons of olfactory sensory neurons (OSN). Axons of these primary sensory neurons traverse the cribriform plate located between the nasal cavity and the brain and bundle together forming the outermost layer of the $\mathrm{OB}$, the olfactory nerve layer. Every type of OSN expresses one out of a repertoire of approximately 1200 receptors in mice ( 350 in humans) (Glusman et al. 2001; Nei et al. 2008). Axons of sensory neurons expressing the same type of olfactory receptor are sorted within this layer and enter the OB together (Mombaerts et al. 1996; Ressler et al. 1994) to form synapses with OB neurons in functional units called glomeruli (Shepherd et al. 2004; Sicard and Holley 1984). The layer these glomeruli form is called the glomerular layer (GL). The GL hosts several types of interneurons, most notably the periglomerular neurons (PGC), a heterogeneous group of GABAergic, and partially dopaminergic neurons, some of which receive direct input from OSNs. Additional cells are the dopaminergic and GABAergic superficial short axon cells (SA), which are characterized by the interglomerular projection of their dendrites, as well as external tufted cells (ETC), glutamatergic neurons showing spontaneous rhythmic activity (for review see (Kosaka and Kosaka 2016)). The GL merges into the external plexiform layer (EPL). In the EPL various types of interneurons can be found as well as the first type of OB output neuron, the tufted cell (TC). The mitral cell (MC), the second type of $\mathrm{OB}$ output neuron, is located in a thin ringlike structure within the $\mathrm{OB}$, the mitral cell layer (MCL). MC and TC both project to primary olfactory cortices but show different projection patterns (Igarashi et al. 2012) as well as different properties in odor processing (Ackels et al. 2020; Economo et al. 2016; Short and Wachowiak 2019). Adjacent to the MCL, the internal plexiform (IPL) layer harbors axons from MC and TC as well as ETC axon collaterals. The GCL comprises granule cells (GC) as well as deep short axon cells (dSA). These two types of inhibitory interneurons receive strong centrifugal inputs and therefore play an essential part in OB neuromodulation.

\section{Different forms of neuromodulatory sources for the olfactory bulb}

Olfaction is, especially in rodents, essential for survival. Mate choice, maternal behavior, food detection, and preference as well as predator avoidance are only a few examples that critically involve the olfactory system. Thus, the plasticity and fine-tuning of olfaction to an animal's needs are especially important. For the OB, a large number of intrinsic and extrinsic modulatory processes have been demonstrated. Extrinsic neuromodulation, i.e., modulation of olfactory processing by sources from outside the $\mathrm{OB}$, can be mediated by neurotransmitters, such as GABA or glutamate, "classic" neuromodulators, like dopamine or serotonin, or by peptides, produced either by neurons (neuropeptides) or by other organs, reaching the OB via the bloodstream (hormones). Figure 1 depicts different extrinsic neuromodulation sources in the OB together with examples of the chemical messengers involved. 
a Olfactory Cortex

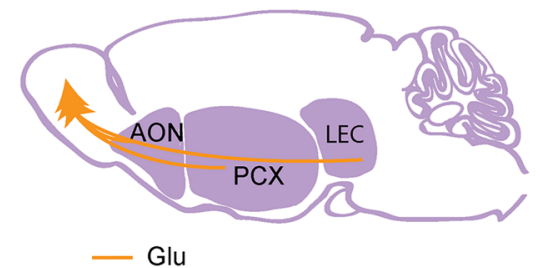

- Glu b Deep Brain Neuromodulatory Centers

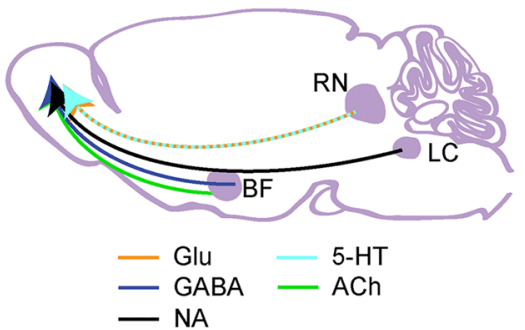

C Neuropeptidergic modulation

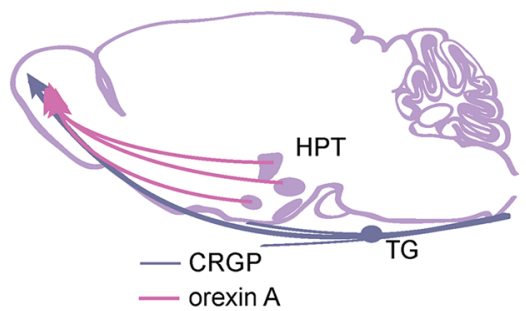

d Hormonal modulation

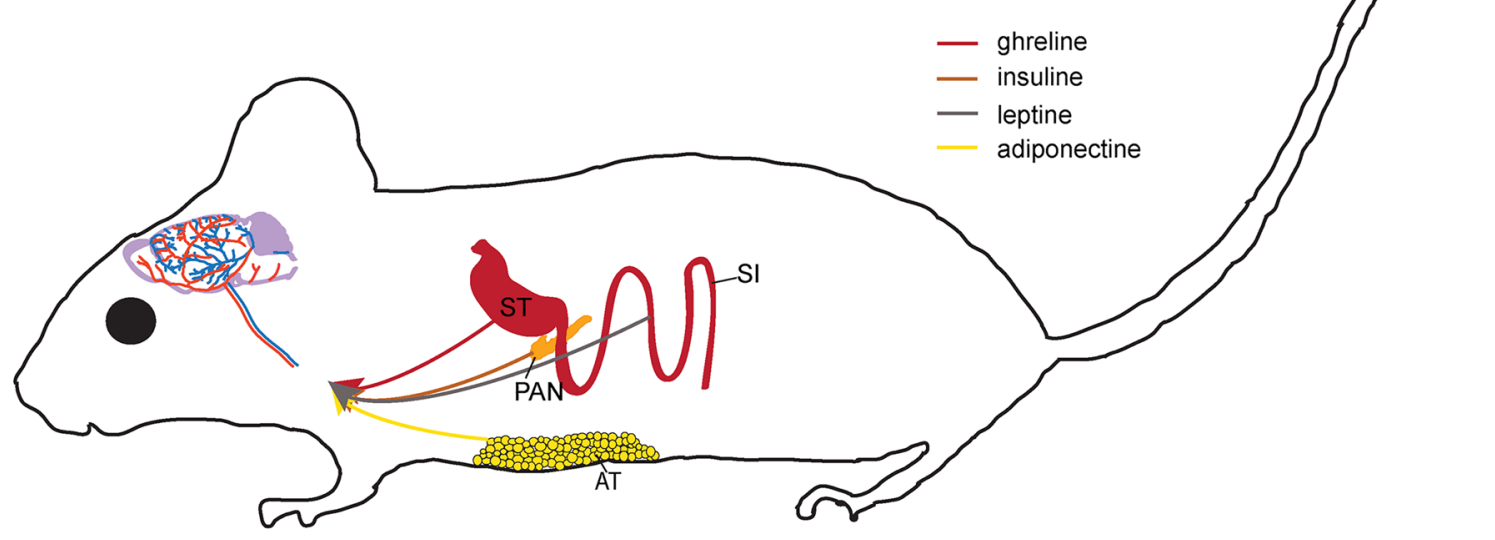

Fig. 1 Types of extrinsic neuromodulatory inputs to the OB. Neuronal (ac) as well as non-neuronal (d) sources of OB effective neuromodulatory cues. Brain-derived sources are marked in light purple while other colors mark sources outside the brain. While neuronal sources stem from fibers of brain centers projecting to the $\mathrm{OB}$, non-neuronal sources secrete their cues to the bloodstream to be effective on OB receptors. (Abbreviations:

\section{Cortical top-down modulation}

The primary olfactory cortex, i.e., areas with direct OB input, comprises the anterior olfactory nucleus, tenia tecta, dorsal peduncular cortex, piriform cortex, olfactory tubercle, nucleus of the lateral olfactory tract, cortical amygdala, and lateral entorhinal area (Igarashi et al. 2012; Neville and Haberly 2004; Wesson 2020).

The OB receives cortical top-down inputs from at least three olfactory cortex areas (Fig. 1a) (Matsutani and Yamamoto 2008), the anterior olfactory nucleus (AON), the piriform cortex (PC), and the lateral entorhinal cortex (LEC). The existence of centrifugal back projections from the olfactory tubercle is currently under debate (De La Rosa-Prieto et al. 2015; Gervais 1979; Heimer 1968; In 't Zandt et al. 2019; Shafa and Meisami 1977; Zhang et al. 2017). Although these OB projections are all glutamatergic, their effects on $\mathrm{OB}$ circuitry are quite complex.
AON anterior olfactory nucleus, PC piriform cortex, LEC lateral entorhinal cortex, RN raphe nuclei, LC locus coeruleus, BF basal forebrain, HPT hypothalamus, TG trigeminal ganglion, ST stomach, SI small intestine, PAN pancreas, AT adipose tissue)

\section{Lateral entorhinal cortex}

The LEC receives (Igarashi et al. 2012) and transfers olfactory information from the OB to the hippocampus (Steward and Scoville 1976). It is involved in the integration of olfactory information and olfactory discrimination learning (Chapuis et al. 2013; Staubli et al. 1984). OB projections arise from the layer II calbindin-positive excitatory neurons of the ventral LEC (Leitner et al. 2016). Due to its large number of afferent inputs, it has been hypothesized that feedback from LEC could provide information about the hedonic state, recent experience, and multisensory events. Additionally, given that LEC neurons are more narrowly tuned to odors than PC neurons ( $\mathrm{Xu}$ and Wilson 2012), it might provide highly odor specific feedback to the OB (Leitner et al. 2016). So far it is unknown how LEC projections modulate odor processing in the OB but it is interesting to note that LEC 
to OB signaling seems to precede odor onset, and thus could potentially prepare the OB for incoming inputs (Kay et al. 1996).

\section{Piriform cortex}

The PC can be separated into two parts, the anterior piriform (aPC) and the posterior piriform cortex (pPC). They receive input from different but overlapping populations of OB output cells (Igarashi et al. 2012; Nagayama et al. 2010) and code for different aspects of odor information (Wilson and Sullivan 2011). Additionally, the aPC has been shown to host a larger number of neurons projecting to the $\mathrm{OB}$ compared with the pPC (Padmanabhan et al. 2016) but the functional relevance of differences between $\mathrm{aPC}$ and $\mathrm{pPC}$ derived $\mathrm{OB}$ projections is, as yet, unclear. $\mathrm{PC}$ inputs to the OB seem to activate predominantly GCs (Boyd et al. 2012; Davis and Macrides 1981; Davis et al. 1978; Pinching and Powell 1972; Price and Powell 1970) which in turn inhibit OB output neurons (Balu et al. 2007; Boyd et al. 2012; Strowbridge 2009). More recently, a visualization of topdown projections from PC into the OB (Boyd et al. 2015; Otazu et al. 2015) displayed projections to the GCL, to target GCs and dSA cells and, to a lesser extent also, to the GL, targeting PG and SA cells. Functionally probing PC-derived fiber activity, as well as effects of PC fiber activation, revealed a possible role for PC fibers in MC decorrelation (Otazu et al. 2015) and sensory gating (Boyd et al. 2012).

\section{Anterior olfactory nucleus}

The AON sends the majority of cortical top-down projections to the OB (Carson 1984; Shipley and Adamek 1984). This olfactory cortex area has been implicated in a range of different functions, including serving as the first site of integrated odor percept formation and reconstructing olfactory memory traces (Aqrabawi and Kim 2020; Haberly 2001; Levinson et al. 2020), social interaction (Oettl et al. 2016; Wacker et al. 2011; Wang et al. 2020), controlling food intake (Soria-Gomez et al. 2014), and integrating activity within and between the two OBs (Esquivelzeta Rabell et al. 2017; Grobman et al 2018; Kikuta et al. 2010; Lei et al. 2006; Schoenfeld and Macrides 1984). AONderived axons have been shown to project to multiple layers of the OB (Padmanabhan et al. 2016; Reyher et al. 1988; Wen et al. 2019) including the GCL, as well as the EPL and the MCL. Furthermore, AON projections are bilateral; i.e., the AON does not only send axons to the ipsilateral but also, via the anterior commissure, to the contralateral OB (Brunjes et al. 2005; Illig and Eudy 2009; Wen et al. 2019). The AON can be divided into two major parts, pars principalis (AONpP) and pars externa (AONpE) (Brunjes et al. 2005). AONpP sends, similar to PC, sensory-evoked feedback to the OB (Rothermel and Wachowiak 2014) but only a few studies have investigated the influence of centrifugal AONpP projections on in vivo $\mathrm{OB}$ circuit function. Activation of AONpP derived fibers strongly inhibits sensory signaling of olfactory output neurons both in the anesthetized (Markopoulos et al. 2012; Medinaceli Quintela et al. 2020) as well as in the awake behaving mouse (Medinaceli Quintela et al. 2020) suggesting a type of gating function. In contrast to that, $\mathrm{AONpE}$ corticofugal projections seem to be exclusively contralateral (Schoenfeld and Macrides 1984; Yan et al. 2008). Neurons within AONpE integrate signals from ipsilateral and contralateral OB (Kikuta et al. 2010), and their projections to the OB seem to link mirror-symmetric MCs and TC with each other (Grobman et al. 2018), possibly to achieve odor perceptual unity.

\section{“Neuromodulatory" projections}

The term "neuromodulatory systems" refers to small neuronal pools grouped in specific nuclei in the brainstem, the mid-brain, and the basal forebrain. Through their widespread projections, neuromodulatory centers can influence many brain regions and have a powerful effect on cognitive behavior (Avery and Krichmar 2017). Neuromodulatory centers include the locus coeruleus for noradrenergic projections, the raphe nuclei for serotonergic projections, the basal forebrain for cholinergic projections, and the ventral tegmental area and substatia nigra for dopaminergic projections (Sara 2009). These centers innervate a large variety of different brain structures which themselves are often highly interconnected, thereby complicating the investigation of each of these modulatory centers on a particular circuit. Though the literature has tried to pin certain functions to each of the neurotransmitters, e.g., acetylcholine mediating attentional processes (D'Souza and Vijayaraghavan 2014; Parikh and Sarter 2008), serotonin influencing mood (Salomon and Cowan 2013), and noradrenaline being responsible for alertness (Waterhouse and Navarra 2018) it becomes more and more apparent that their function is far more complex and even direct interactions between neuromodulatory systems have to be considered (e.g., cholinergic innervation of raphe (Kalen and Wiklund 1989)).

The OB receives centrifugal projections from at least three of these neuromodulatory systems (Fig. 1b), the locus coeruleus (LC), the basal forebrain (BF), and and the raphe nuclei. Also, a direct dopaminergic input to the OB from substatia nigra has been suggested (Hoglinger et al 2015). However, while there are clear effects of dopaminergic neuron ablation detectable in the OB circuitry (Zhang et al. 2015) and olfactory perception (Hoglinger et al. 2015), it is still unclear if this is due to a direct connection, since earlier results (Hoglinger et al. 2015) could not be confirmed by 
Fig. 2 Targets of projections from neuromodulatory centers. Innervation strength and putatively affected $\mathrm{OB}$ cells for fibers from locus coeruleus (a, yellow), raphe nuclei (b, blue), and basal forebrain (c, green). Putatively affected cell types in the basal scheme of the olfactory bulb neuronal circuits are marked in black for each neuromodulatory center. Relative innervation density is marked on the right as color depth. OB modulation from $\mathrm{BF}$ is separated into cholinergic $(\mathrm{ACh})$ and $\mathrm{GABAergic}(\mathrm{GABA})$ fibers, while innervation from raphe nuclei is separated into fibers coming from median (MRN) and dorsal raphe (DRN). (Abbreviations: ONL olfactory nerve layer, GL glomerular layer, EPL external plexiform layer, MCL mitral cell layer, IPL internal plexiform layer, GCL granule cell layer, ON olfactory nerve, PG periglomerular cells, SA short axon cells, ETC external tufted cells, MT mitral and tufted cells, GC granule cells, dSA deep short axon cells)

newer tracing studies (Padmanabhan et al. 2018; Schneider et al. 2020; Vinograd et al. 2019; Wen et al. 2019). Thus we will focus on the remaining three modulatory centers (Fig. 2), discussing their OB innervation, targets, cellular activity modifications, and behavioral effects.

\section{Locus coeruleus}

The LC was the first neuromodulatory center characterized anatomically and neurochemically (reviewed in Chandler et al. 2019). The LC is located deep in the pons and contains only about 1500 neurons per hemisphere in rodents. Despite its small number of cells, recent studies suggest that the LC could be subdivided into different modules enabling targeted neuromodulation (Plummer et al. 2020; Uematsu et al. 2017). Immunohistochemical evidence indicates that the vast majority of LC neurons are noradrenergic (Grzanna and Molliver 1980).

The LC is the major source of forebrain noradrenaline (NA, norepinephrine) and sends projections to almost all brain regions (Sara 2009). Its activity is commonly associated with arousal (e.g., O'Hanlon 1965; reviewed in, e.g., Berridge and Waterhouse 2003: Sara and Bouret 2012). LC noradrenergic fibers reach all OB layers with the lowest and highest density in the glomerular and internal plexiform layer, respectively (Fig. 2a) (McLean et al. 1989). Consistent with this distribution, the effect of NA in the GL has received very little attention but newer results show that electrical LC stimulation elicits a global and persistent inhibition of OB input signals (Eckmeier and Shea 2014). Additionally, an excitatory role for beta-adrenergic receptors on the firing and bursting frequency of ETCs could be demonstrated (Zhou et al. 2016). Research on noradrenergic modulation of $\mathrm{OB}$ output initially created conflicting results with studies reporting either excitatory or inhibitory effects (Hayar et al. 2001; Jahr and Nicoll 1982; McLennan 1971; Mouly et al. 1995; Okutani et al. 1998; Perez et al. 1987; Salmoiraghi et al. 1964). More recent research was able to resolve these discrepancies and show that besides a
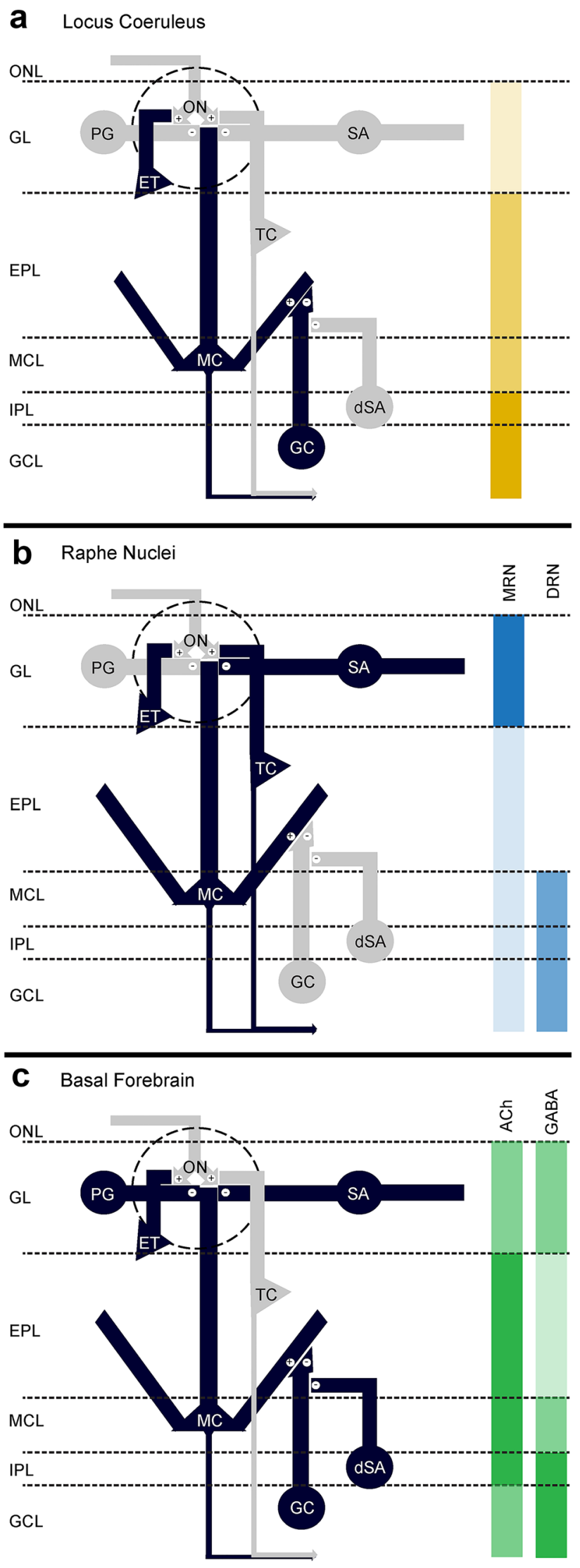
direct excitation of MC firing through activation of the a1A-adrenergic receptor (Ciombor et al. 1999), NA also affects GCs concentration-dependently through $\alpha 1 \mathrm{~A}$ receptors, thereby increasing inhibitory drive from GCs onto MCs (Zimnik et al. 2013) and through $\alpha 2 \mathrm{~A}$ decreasing this inhibitory drive (Nai et al. 2009, 2010; Pandipati et al. 2010). The bidirectional modulation of GCs is elicited by a change in GC subthreshold membrane potential and thus excitability (Li et al. 2015; Nai et al. 2010). Further, it has been shown that LC activation reduces spontaneous MC activity while enhancing odorant responses (Manella et al. 2017). The net effect of LC-derived OB activation and inhibition was suggested as a mechanism to enhance signal-to-noise levels, a function that has been attributed to the LC in multiple sensory systems (McBurney-Lin et al. 2019). Consistent with a decrease in signal to noiseratio, behavioral tests showed that noradrenergic modulation affects odor detection (Escanilla et al. 2012, 2010; Linster et al. 2011) and discrimination (Doucette et al. 2007; Ramirez-Gordillo et al. 2018). Additionally, the LC seems to affect OB olfactory memory encoding profoundly. The depletion of LC neurons decreased odor habituation, which could be counteracted by local bulbar NA infusions (Guerin et al. 2008). Also, reward-driven discrimination of very similar odors could be affected by NA through an interplay of $\alpha$ and $\beta$ adrenergic receptors (Doucette et al. 2007; Mandairon et al. 2008), while new research shows an effect of NE on memory stability in the OB (Linster et al. 2020).

\section{Raphe nuclei}

The serotonergic neuromodulatory system is involved in a wide range of physiological brain functions including memory, circadian rhythm, feeding, sleep-wake cycle, and stress coping (Filip and Bader 2009) and has been implicated in several neurological diseases. It represents the most diverse CNS signaling network (Grandjean et al. 2019) comprising a range of neurons displaying divergent cellular properties in terms of anatomy, morphology, hodology, electrophysiology, and gene expression (Okaty et al. 2019).

The source of all serotonergic projections is located in the brain stem in the form of nine distinct neuronal clusters (Dahlstroem and Fuxe 1964). Two of those seem to be the source of OB innervation: B7, which belongs to the dorsal raphe nucleus (DRN), and $\mathrm{B} 8$, which is part of the median raphe nucleus (MRN) (Muzerelle et al. 2016). Those nuclei differentially target the OB with the DRN projecting to deeper layers, specifically the MCL and GCL, while the MRN projects almost exclusively to the GL (Fig. 2b) (Muzerelle et al. 2016; Steinfeld et al. 2015). Single serotonergic fibers have been shown to possess varicosities in all layers of the $\mathrm{OB}$ and to form synapses with chemically heterogeneous cell populations (Suzuki et al. 2015).

The range of different serotonin receptors expressed in the $\mathrm{OB}$ further complicates revealing its function. At least eight of the 14 known subtypes of serotonin receptors seem to be expressed in the rodent OB (Filip and Bader 2009; Gaudry 2018), most of which have not yet been characterized functionally.

Though far from being exhaustively investigated, several modulation mechanisms for serotonin in the OB have been shown. The most prominent effect is an activation of periglomerular SAs (Brill et al. 2016; Brunert et al. 2016; Hardy et al. 2005a; Petzold et al. 2009) through 5-HT2C receptors. This leads to a reduction of presynaptic OSN activity (Petzold et al. 2009) while increasing inhibitory drive in the glomeruli. At the same time, ETCs are strongly activated, either through 5-HT 2A receptors (Brill et al. 2016; Liu et al. 2012) or glutamatergic input from raphe-derived fibers (Kapoor et al. 2016). Such dual release of glutamate and 5-HT from raphe fibers has been also shown in other brain areas like VTA (Wang et al. 2019). Output neurons can be directly activated by serotonin (Schmidt and Strowbridge 2014), in parts through 5-HT 2A receptors (Hardy et al. 2005a) or potentially also directly inhibited by 5 -HT1a and/or 5-HT1b receptors (Kapoor et al. 2016). The net effect on MCs and TCs differs, while optogenetic activation of raphe-derived fibers led to TC excitation, and ultimately to a larger response correlation, MCs showed bimodal effects that led to a decorrelation of odor responses (Kapoor et al. 2016).

Despite this clear evidence for serotonin modulation of cellular activity, it is unclear how this affects olfactory behavior. So far, two studies looked at olfactory related behavior after depletion of the serotonergic system. None of them were able to establish a significant phenotype for serotonin depleted mice in different assays testing coarse olfactory performance (Carlson et al. 2016; Liu et al. 2011). Still, not only the described changes in $\mathrm{OB}$ cell activity but also the differentiated innervation and extensive compensatory regulation of serotonergic fiber density in the GL upon olfactory sensory deprivation (Gomez et al. 2006) make a lack of serotonergic function in the OB unlikely. More specific serotonergic targeting techniques as well as more refined olfactory tests, like discrimination of very similar odor mixtures or detection of low odor concentrations, will most likely reveal deeper insights into serotonergic function.

\section{Basal forebrain}

The BF is, like the raphe, a complex of subcortical nuclei, including the medial septum, vertical and horizontal limbs of the diagonal band, the magnocellular preoptic nucleus, and the substantia innominata. BF neuromodulatory systems are thought to enhance sensory processing and amplify the signal-to-noise ratio of relevant responses (Disney et al. 2007; 
Goard and Dan 2009; Picciotto et al. 2012; Sarter et al. 2005) as well as being key players in mediating attentional modulation of sensory processing and coordinating cognitive operations. So far, most of these functions have been attributed to cholinergic signaling but most BF nuclei also contain GABAergic as well as glutamatergic projection neurons (Agostinelli et al. 2019; Gritti et al.2006; Henny and Jones 2008; Yang et al. 2017; Zaborszky et al. 2015).

The olfactory system is heavily innervated by centrifugal inputs from the $\mathrm{BF}$ with the majority of bulbopetal neurons located in the horizontal dorsal band of Broca (HDB) (Gielow and Zaborszky 2017; Gracia-Llanes et al. 2010; Li et al. 2018; Shipley and Adamek 1984; Zaborszky et al. 1986, 2015). So far, there is knowledge on cholinergic and GABAergic projection fibers in the $\mathrm{OB}$ though they seem to make up only about $50 \%$ of HDB derived projections to the OB (Zaborszky et al. 1986). Cholinergic and GABAergic bulbopetal cells show an overlapping but largely segregated pattern in BF (Zaborszky et al. 1986) and innervate the OB layers differently (Bohm et al. 2020). ChAT-positive cholinergic axon terminals are visible in all layers of the OB (Fig. 2c) (Bohm et al. 2020; Durand et al. 1998; Gomez et al. 2005; Macrides et al. 1981; Rothermel et al. 2014; Salcedo et al. 2011) but innervate the superficial OB layers rather homogeneously compared with the GCL, which receives less input. Glutamate decarboxylase (GAD) 2-positive GABAergic axon terminals, in contrast, show a strong innervation of the glomerular and the GCL with weaker innervation of EPL and MCL (Fig. 2c) (Bohm et al. 2020: Nunez-Parra et al. 2013). Fine structural observations show that cholinergic projections synapse primarily onto interneurons (Kasa et al. 1995; Nickell and Shipley 1988) but extrasynaptic transmission is, like for all neuromodulatory transmitters, a well-known feature (Fuxe et al. 2012).

In the OB nicotinic as well as muscarinic acetylcholine receptors are expressed. So far nicotinic acetylcholine receptor (nAChR) subunits $\alpha 2, \alpha 3, \alpha 4, \alpha 5, \alpha 6, \alpha 7$, and $\alpha 9$ (Keiger and Walker 2000) as well as muscarinic acetylcholine receptors (mAChRs) M1 and M2 (Le Jeune et al. 1995) have been detected. mAChRs are present primarily in the EPL and GL (Hunt and Schmidt 1978; Le Jeune et al. 1995) and while M1 activation enhances GC excitation, leading to suppression of MTC excitability (Pressler et al. 2007; Smith and Araneda 2010), M2 seems to exert its function in the GL (Bendahmane et al. 2016). Effects have varied from excitation of MTC glomerular responses (Bendahmane et al. 2016) to an inhibition of MC and ETC spiking due to activation of inhibitory interneurons (Liu et al. 2015). nAChRs have mainly been found in the GL and MCL (Hunt and Schmidt 1978; Le Jeune et al. 1995). So far, functional nAChRs have been located on MCs and ETCs (D'Souza et al. 2013; D'Souza and Vijayaraghavan 2012) but recent research also suggests $\alpha 2$ subunit-containing nAChRs on dSAs (Burton et al. 2017; Case et al. 2017). Studies on nAChR signaling in the OB have focused mainly on receptors on ETCs and MCs and found that $\mathrm{ACh}$ application or optogenetic $\mathrm{OB}$ cholinergic fiber activation in slices leads to a direct MC and ETC activation (D'Souza et al. 2013; D'Souza and Vijayaraghavan 2012; Liu et al. 2015). Overall, observed ACh effects on OB odor processing reach from input independent sensory gain modulation (Bohm et al. 2020; Rothermel et al. 2014) similar to reports in visual cortex (D'Souza et al. 2013; D'Souza and Vijayaraghavan 2012; Parsa et al. 2015) to low pass filtering (Bendahmane et al. 2016) and sharpening of receptive fields (Ma and Luo 2012).

The role of BF-derived GABAergic fibers in the $\mathrm{OB}$ has been much less investigated. GABAergic fibers from HDB and the magnocellular preoptic nucleus have been shown to influence GCs (Nunez-Parra et al. 2013), dSAs (Case et al. 2017), and different PGCs (Sanz Diez et al. 2019). A recent study reported that optogenetic activation of GABAergic fibers in the OB caused inhibition of spontaneous and weak sensory activity while increasing odor-evoked responses (Bohm et al. 2020). This suggests a function for the GABAergic BF system in the modulation of signal-to-noise ratio or high pass filtering weak sensory inputs. Little is known on the behavioral effects of GABAergic OB modulation except that pharmacological inactivation of GABAergic fibers impairs olfactory sensitivity (Nunez-Parra et al. 2013). In contrast, cholinergic BF fibers have been shown to improve odor discrimination ability (Chaudhury et al. 2009; Cleland et al. 2002; Doty et al. 1999; Li and Cleland 2013; Mandairon et al. 2006) as well as to facilitate olfactory learning and memory (Devore and Linster 2012; Ravel et al. 1994; Ross et al. 2019). Future studies will shed light on the function and interplay of the cholinergic and GABAergic BF system, how it influences $\mathrm{OB}$ odor processing, and its impact on olfactory guided behavior.

\section{Neuropeptidergic modulation}

A large number of neuropeptides can modulate OB function, and most of them are generated locally within the OB, e.g., somatostatin (SOM; Nocera et al. 2019), glucagon-like peptide 1 (GLP-1; Thiebaud et al. 2019), pituitary adenylate cyclase-activating polypeptide (PACAP; Irwin et al. 2015), or the circadian rhythm mediating vasoactive intestinal polypeptide (VIP; Lukas et al. 2019; Miller et al. 2014). Since some neuropeptides, like substance $\mathrm{P}$ or enkephalins, are located both in local cells and in axonal fibers in the OB (Halasz and Shepherd 1983), effects cannot be assigned to extrinsic or intrinsic sources. Additionally, there are neuropeptides found exclusively in secretory fibers from other neuronal centers that project to the OB (Fig. 1c), like, e.g., calcitonin generelated peptide (CGRP)-containing fibers from the trigeminal ganglion. These fibers were reported to reduce the activity of 
OB interneurons, thus mediating interaction between trigeminal and odorant sensations (Genovese et al. 2016).

Another example is orexin-A. Orexin is a neuropeptide involved in sleep/wake regulation (Sakurai et al. 2010) as well as feeding behavior (Horvath and Gao 2005; Sakurai et al. 1998). Orexin-positive fibers from the lateral hypothalamus have been shown in the OB (Gascuel et al. 2012; Peyron et al. 1998) with varicose fibers located predominantly in the GL, MCL, and GCL (Caillol et al. 2003). Orexin receptors 1 and 2 are expressed in PGCs, MCs/TCs, and GCs, and orexinA was shown to directly activate and indirectly inhibit MC activity (Hardy et al. 2005b) suggesting an additional way of metabolic regulation of olfactory processing.

Another neuropeptide that has received attention in recent years is oxytocin (OTX), which controls childbirth and is strongly involved in social behaviors. OTX released in the forebrain mainly originates from neurons in the paraventricular nucleus of the hypothalamus (Knobloch et al. 2012). Recently, it has been reported that same-sex social recognition in mice is OTX dependent (Linster and Kelsch 2019, Oettl et al. 2016). OTX was shown to activate AON cells projecting to the OB thereby modulating MC firing (Oettl et al. 2016). Together with the absence of detectable OTX fibers in the OB (Knobloch et al. 2012), this is casting doubt on a direct effect of OTX in the OB. However, the weak but clear presence of oxytocin receptors in the OB (Ferguson et al. 2000; Ferris et al. 2015; Vaccari et al. 1998), the effects of OTX infused into the OB on maternal behavior (Yu et al. 1996a), and MC firing (Yu et al. 1996b), as well as the fact that expression of oxytocin and its receptors is highly regulated (Freund-Mercier et al. 1994), open up the question of a to-date unknown or just undetected function of OTX for the OB.

\section{Hormonal neuromodulation}

Despite its importance for mating and nutrition, hormonal neuromodulation is a field that has received less attention. The OB is well-positioned for hormonal neuromodulation; certain blood molecules can reach the OB more easily compared with other brain areas since the density of the blood capillary network, especially in the GL, is very high (Lecoq et al. 2009) and the blood-brain barrier at the OB is more permeable (Ueno et al. 1996). A specialized transport system for certain hormones provides an additional means to increase the local concentration of those hormones within the OB (Banks et al. 1999).

Hormones have many diverse functions, e.g., sex steroids like testosterone or estradiol, that regulate sexual differentiation and behavior (McEwen and Milner 2017); neurohormones like melatonin, which affects circadian rhythms (Brown 1994); and metabolic hormones like ghrelin and insulin (Julliard et al. 2017). Receptors for both estrogens
(Hoyk et al. 2014, Maruska and Fernald 2010) and melatonin (Corthell et al. 2014) are expressed in the OB, and hormonal effects could be demonstrated (Corthell et al. 2014; Dillon et al. 2013). However, the presence of synthesizing enzymes for these hormones within the OB (Corthell et al. 2014; Hoyk et al. 2014) speaks rather for a local neuropeptidergic function.

Remotely produced hormones that act on OB cells have so far been linked to the metabolic regulation of food intake (see (Palouzier-Paulignan et al. 2012). The olfactory system is known for its major contribution to the hedonic evaluation of food (with effects on food choices and consumption), and it seems to make sense that olfaction would be modulated according to foraging needs (Julliard et al. 2017). Foraging influencing hormones are divided into orexigenic (appetite-stimulating) and anorexigenic (appetite-suppressing) hormones. So far, ghrelin and adiponectin as orexigenic molecules and insulin and leptin as anorexigenic molecules have been identified. These hormones have different sources (Fig. 1d): ghrelin is produced primarily by the stomach (Kojima et al. 1999), leptin is predominantly generated by adipose cells and enterocytes in the small intestine (Bado et al. 1998), adiponectin is synthesized predominantly in adipose tissue (Scherer et al. 1995), while insulin is released by pancreatic beta cells in response to feeding state in a glucosedependent manner (Henquin 2011).

The best-investigated metabolic hormone with a function in the $\mathrm{OB}$ is insulin. The $\mathrm{OB}$ shows the highest insulin receptor (insulin kinase) density in the whole brain (Hill et al. 1986) and insulin has been shown to cause an increase in firing frequency and inhibition of spike adaptation in OB MCs (Fadool et al. 2000). As a substrate, the voltageactivated $\mathrm{K}+$ channel Kv1.3 has been identified which, when phosphorylated by insulin receptor kinase, is causing a change in MC excitability (Fadool et al. 2011). Adiponectine receptors have been found in all $\mathrm{OB}$ cell layers, and $\mathrm{OB}$ adiponectine injection was found to regulate the expression of insulin receptors (Miranda-Martinez et al. 2017).

Ghrelin is transported across the blood-brain barrier and is present in high concentrations in the OB (Rhea et al. 2018). So far only one ghrelin receptor has been identified, growth hormone secretagogue receptor (GHSR-1a) which is expressed in GL and MCL (Tong et al. 2011). Functionally, ghrelin has been shown to increase exploratory sniffing behavior and olfactory sensitivity but it is unclear whether this effect is due to local ghrelin signaling.

The OB has also high levels of leptin receptors (Shioda et al. 1998) but despite studies showing leptin decreasing olfactory sensitivity (Julliard et al. 2007) and an increase in performance of leptin-deficient mice in olfactory detection (Getchell et al. 2006) and memory tasks (Chelminski et al. 2017), the cellular mechanisms of these changes remained unclear for a long time. Only recently it was shown 
that leptin decreases the excitability of MCs/TCs as well as GCs through direct modulation of a voltage-sensitive potassium channel which leads to a net inhibition of the MTC population and negatively affects discrimination performance (Sun et al. 2019).

As mentioned for ghrelin, it is not exactly clear if the orexigenic and anorexigenic effects of the hormones are caused by their effects in OB circuits or if changing the sense of smell is a secondary effect. Global developments of increased obesity and subsequent research in diet and metabolism will shed more light on this relationship.

\section{Open questions concerning neuromodulation in the olfactory bulb}

There are many unresolved questions in the field of olfactory neuromodulation; maybe the most prominent being when and how modulatory processes are used in olfactory behavior. An important step in this direction is defining the nature of $\mathrm{OB}$ projection neurons. New tracing techniques are not only able to label cells in higher brain areas according to their postsynaptic targets but also allow for a defined characterization of their inputs (Schwarz et al. 2015). First results defining the input-output relations of different brain centers indicate that there are great differences between neuromodulatory systems, with, e.g., the $\mathrm{LC}$ rather resembling a homogenous integrator and broadcaster of information (Schwarz et al. 2015), while input-output relations in the BF seem to be much more specific (Gielow and Zaborszky 2017). Other technical advances in, e.g., the development of faster, more sensitive optogenetic tools for cell type-specific dissection of brain circuits (Lee et al. 2020), increasing spatial resolution for deep brain imaging (Vasquez-Lopez et al. 2018), and enhancing sensitivity and expression of genetically coded calcium dyes (Dana et al. 2019) will help to advance our knowledge on the specific functions of different neuromodulatory systems in olfactory guided behaviors.

Another topic that bears consideration are the numerous interactions between different brain areas providing modulatory input to the $\mathrm{OB}$. These interactions can occur outside of the OB but also influence their input to and neuromodulation in the OB. The AON for example sends odor specific feedback to the OB but also receives input from olfactory cortical areas like the aPC (Haberly 2001; Haberly and Price 1978; Luskin and Price 1983) as well as non-olfactory areas such as BF (Broadwell and Jacobowitz 1976; Carnes et al. 1990; De Carlos et al. 1989; Gaykema et al. 1990; Luiten et al. 1987; Zaborszky et al. 2012). The AON has also been implicated as the mediator of hypothalamic oxytocin effects on OB olfactory processing (Oettl et al. 2016). However, such interactions can also occur inside the OB where ACh (Zhou et al. 2018), endocannabinoids (Pouille and Schoppa 2018), and GABA (Mazo et al. 2016) have been shown to modulate synapses between corticofugal fibers and cells of the OB.

A huge step forward would also be the detailed characterization of projecting neurons in terms of transmitter release inside the OB. The here described BF, which has been classically associated with cholinergic modulation, is a good example. Cholinergic and GABAergic neurons account only for about $50 \%$ of all BF-derived bulbopetal neurons (Zaborszky et al. 1986) leaving open the functional contribution of the remaining half. Additionally, most bulbopetal fibers are at least suspected to contain more than one transmitter. Glutamatergic effects upon stimulation of serotonergic OB fibers (Kapoor et al. 2016) and GABA and ACh corelease by a subpopulation of OB projecting HDB neurons are just two examples (Case et al. 2017).

Another interesting topic is the plasticity of neuromodulatory systems. Apart from developmental changes in the embryonic phase, top-down systems are also highly plastic in postnatal mice. For example, sensory deprivation through unilateral naris occlusion was shown to change cholinergic innervation patterns in the OB (Salcedo et al. 2011) though overall fiber density remained unchanged (Gomez et al. 2006; Salcedo et al. 2011). Noradrenergic OB input is even more plastic and shows a strong change in LC derived fiber density (Gomez et al. 2006), as well as adrenergic receptor expression upon reduced sensory input. Additionally, neuromodulatory effects are not homogenously distributed across different OB glomeruli. Both, serotonergic (Gomez et al. 2005) and cholinergic fibers (Gomez et al. 2005; Macrides et al. 1981; Salcedo et al. 2011), have been shown to innervate some glomeruli stronger than others but the functional significance is unknown.

Finally, one question that has received more interest of late is adult neurogenesis. A distinguishing feature of the $\mathrm{OB}$ is its lifelong integration of adult-born neuronal progenitors into its inhibitory circuits. OB neurogenesis has been shown as an important factor for olfactory processing (Livneh et al. 2014), odor discrimination (Gheusi et al. 2000; Mouret et al. 2009), and odor learning (Alonso et al. 2012; Lazarini et al. 2009; Sultan et al. 2010). Several recent reviews stress the importance of adult neurogenesis for olfactory function (Hanson et al. 2017; Lledo and Valley 2016; Takahashi et al. 2018). Neuronal progenitors for adult OB neurogenesis stem from the subventricular zone (SVZ) along the walls of the brain's lateral ventricle (Merkle et al. 2007) where a pool of dividing astrocytes constantly produces new neuroblasts (Doetsch et al. 1999). From the SVZ neuroblasts migrate tangentially along the rostral migratory stream to the core of the $\mathrm{OB}$, then radially to the superficial GCL and, to a lesser extent, the GL (Lepousez et al. 2013; Lledo et al. 2006). It has been estimated that in young adult rodents $10,000-30,000$ neuroblasts 

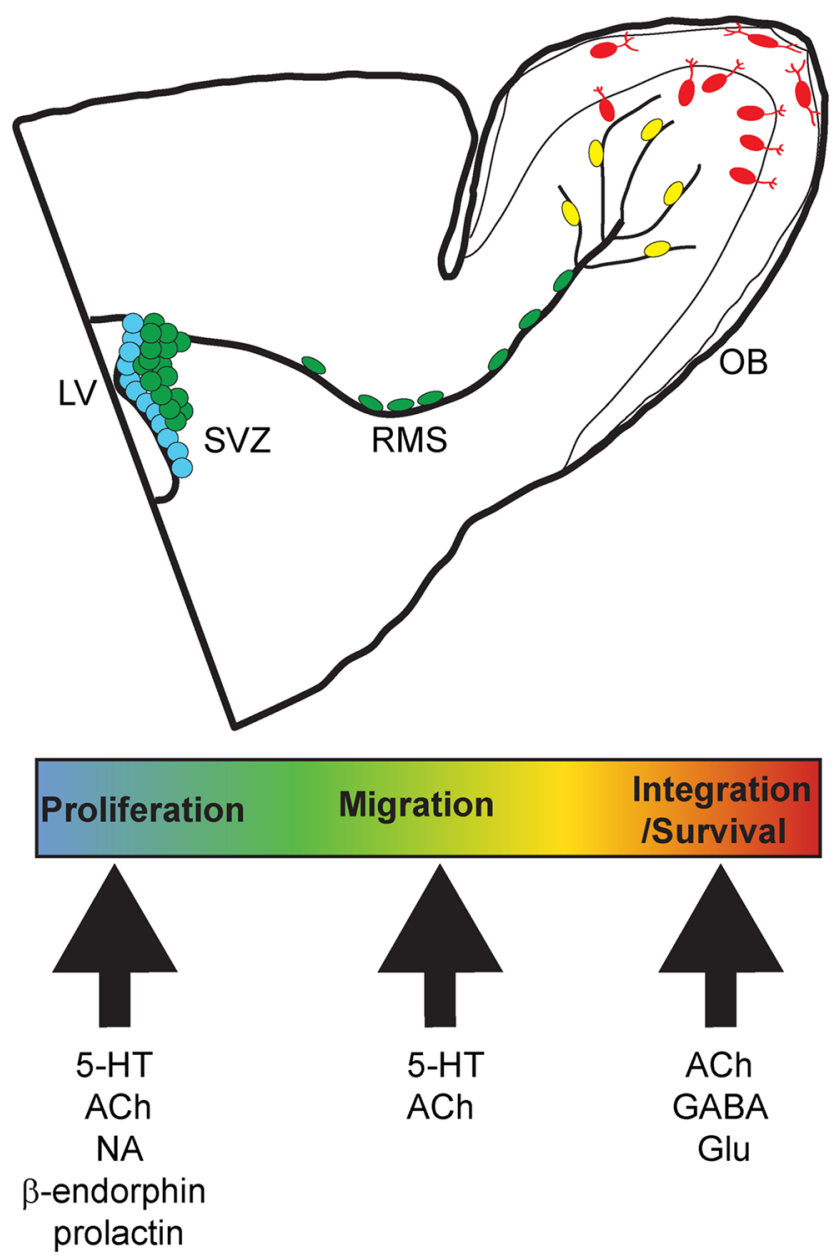

Fig. 3 Neuromodulatory influences in adult neurogenesis (adapted from (Rikani et al. 2013). Neuromodulatory transmitters coming from deep brain neuromodulatory centers, olfactory cortex, or hypothalamus can influence olfactory processing not only by immediate effects but also by acting on proliferation (blue), migration (tangential (green), radial (yellow)), or differentiation and survival (red) of adult-born neurons. Neuromodulators acting on a specific process are listed under the respective arrows. (Abbreviations: OB olfactory bulb, RMS rostral migratory stream, SVZ subventricular zone, LV lateral ventricle)

per day reach the OB (Lois and Alvarez-Buylla, 1994); however, only $50 \%$ of those cells survive for more than a month (Petreanu and Alvarez-Buylla 2002), suggesting a rigorous selection process. Numerous studies have shown that new interneurons can be influenced in all phases of their generation, migration, and integration and that this influence is mediated by multiple neuronal messengers from different sources (see Fig. 3). For example, all classical neuromodulators seem to influence adult neurogenesis like, e.g., acetylcholine, either from local sources (PaezGonzalez et al. 2014) or BF derived fibers, regulates the proliferation, migration, and survival of adult-born neurons (Kaneko et al. 2006; Mechawar et al. 2004; Paez-Gonzalez et al. 2014; Sharma 2013). Additionally, new research has shown that HDB GABAergic fibers target immature GCs upon arrival in the $\mathrm{OB}$ and promote their survival (Hanson et al. 2020). Other neuromodulators involved are 5-HT that acts on proliferation and migration (Banasr et al. 2004; Garcia-Gonzalez et al. 2017), dopamine that increases proliferation (Hoglinger et al. 2004), and norepinephrine (Weselek et al. 2020) acting on proliferation in the SVZ. Other modulatory influences on OB neurogenesis come from cortical fibers that reach into the GCL and establish synaptic connections to newborn neurons (Arenkiel et al. 2011; De La Rosa-Prieto et al. 2015; Deshpande et al. 2013). Activation of these fibers can induce LTP (Nissant et al. 2009) as well as experience-dependent plasticity (Lepousez et al. 2014) and thus seems to promote the survival of these neurons. Other examples are neuropeptides like prolactin from the pituitary gland during pregnancy (Shingo et al. 2003) or $\beta$-endorphin from hypothalamic neurons in hunger and satiety (Paul et al. 2017). Taken together neuromodulatory changes in neurogenesis will be of great interest in the future, especially since a recent paper demonstrated that cholinergic effects on olfactory learning require adult neurogenesis (Schilit Nitenson et al. 2019).

\section{Conclusion}

In this review, we have aimed to give a broad overview on extrinsic neuromodulation of the OB. The discussed list of external OB neuromodulatory sources is, however, by no means complete. Increasingly sensitive tracing techniques are already expanding the list of centrifugal inputs to the $\mathrm{OB}$ (Padmanabhan et al. 2018; Schneider et al. 2020; Wen et al. 2019) and studies on transcriptomes of OB cells might also increase knowledge on hormonal receptors.

In summary, we can say that although most bulbopetal connections have been characterized more than 40 years ago, we are still far away from getting a comprehensive view of processes that lead to modulation of early olfactory processing. Given the intense role of neuromodulation in neurological diseases (see, e.g., Avery and Krichmar 2017), more research is needed in this field.

Acknowledgments The authors thank the members of the Rothermel lab for helpful suggestions and comments.

Funding Open Access funding enabled and organized by Projekt DEAL. This work was supported by funding from DFG (RO4046/2-1 and /2-2), Emmy Noether Program (to MR) the Research Training Group "MultiSenses-MultiScales: novel approaches to decipher neural processing in multisensory integration" 368482240/GRK2416 (to MR) and the Interdisciplinary Center for Clinical Research within the faculty of Medicine at the RWTH Aachen University Grant IZKF TN1-7532007 (to MR). 


\section{Compliance with ethical standards}

Ethical approval This article does not contain any studies with human participants or animals performed by any of the authors.

Conflict of interest The authors declare that they have no competing interests.

Open Access This article is licensed under a Creative Commons Attribution 4.0 International License, which permits use, sharing, adaptation, distribution and reproduction in any medium or format, as long as you give appropriate credit to the original author(s) and the source, provide a link to the Creative Commons licence, and indicate if changes were made. The images or other third party material in this article are included in the article's Creative Commons licence, unless indicated otherwise in a credit line to the material. If material is not included in the article's Creative Commons licence and your intended use is not permitted by statutory regulation or exceeds the permitted use, you will need to obtain permission directly from the copyright holder. To view a copy of this licence, visit http://creativecommons.org/licenses/by/4.0/.

\section{References}

Ackels T, Jordan R, Schaefer AT, Fukunaga I (2020) Respiration-locking of olfactory receptor and projection neurons in the mouse olfactory bulb and its modulation by brain state. Front Cell Neurosci 14:220

Agostinelli LJ, Geerling JC, Scammell TE (2019) Basal forebrain subcortical projections. Brain Struct Funct 224:1097-1117

Alonso M, Lepousez G, Sebastien W, Bardy C, Gabellec MM, Torquet N, Lledo PM (2012) Activation of adult-born neurons facilitates learning and memory. Nat Neurosci 15:897-904

Aqrabawi AJ, Kim JC (2020) Olfactory memory representations are stored in the anterior olfactory nucleus. Nat Commun 11:1246

Arenkiel BR, Hasegawa H, Yi JJ, Larsen RS, Wallace ML, Philpot BD, Wang F, Ehlers MD (2011) Activity-induced remodeling of olfactory bulb microcircuits revealed by monosynaptic tracing. PLoS ONE 6:e29423

Avery MC, Krichmar JL (2017) Neuromodulatory systems and their interactions: a review of models, theories, and experiments. Front Neural Circuits 11:108

Bado A, Levasseur S, Attoub S, Kermorgant S, Laigneau JP, Bortoluzzi MN, Moizo L, Lehy T, Guerre-Millo M, Le Marchand-Brustel Y, Lewin MJ (1998) The stomach is a source of leptin. Nature 394:790-793

Balu R, Pressler RT, Strowbridge BW (2007) Multiple modes of synaptic excitation of olfactory bulb granule cells. J Neurosci 27:5621-5632

Banasr M, Hery M, Printemps R, Daszuta A (2004) Serotonin-induced increases in adult cell proliferation and neurogenesis are mediated through different and common 5-HT receptor subtypes in the dentate gyrus and the subventricular zone. Neuropsychopharmacology 29:450-460

Banks WA, Kastin AJ, Pan W (1999) Uptake and degradation of bloodborne insulin by the olfactory bulb. Peptides 20:373-378

Bendahmane M, Ogg MC, Ennis M, Fletcher ML (2016) Increased olfactory bulb acetylcholine bi-directionally modulates glomerular odor sensitivity. Sci Rep 6:25808

Berridge CW, Waterhouse BD (2003) The locus coeruleus-noradrenergic system: modulation of behavioral state and state-dependent cognitive processes. Brain Res Brain Res Rev 42:33-84
Bohm E, Brunert D, Rothermel M (2020) Input dependent modulation of olfactory bulb activity by HDB GABAergic projections. Sci Rep 10:10696

Boyd AM, Kato HK, Komiyama T, Isaacson JS (2015) Broadcasting of cortical activity to the olfactory bulb. Cell Rep 10:1032-1039

Boyd AM, Sturgill JF, Poo C, Isaacson JS (2012) Cortical feedback control of olfactory bulb circuits. Neuron 76:1161-1174

Brill J, Shao Z, Puche AC, Wachowiak M, Shipley MT (2016) Serotonin increases synaptic activity in olfactory bulb glomeruli. J Neurophysiol 115:1208-1219

Broadwell RD, Jacobowitz DM (1976) Olfactory relationships of the telencephalon and diencephalon in the rabbit. III. The ipsilateral centrifugal fibers to the olfactory bulbar and retrobulbar formations. J Comp Neurol 170:321-345

Brown GM (1994) Light, melatonin and the sleep-wake cycle. J Psychiatry Neurosci 19:345-353

Brunert D, Rothermel M (2019) Neuromodulation of early sensory processing in the olfactory system. Neuroforum 25:25

Brunert D, Tsuno Y, Rothermel M, Shipley MT, Wachowiak M (2016) Cell-type-specific modulation of sensory responses in olfactory bulb circuits by serotonergic projections from the raphe nuclei. J Neurosci 36:6820-6835

Brunjes PC, Illig KR, Meyer EA (2005) A field guide to the anterior olfactory nucleus (cortex). Brain Res Brain Res Rev 50:305-335

Bucher D, Marder E (2013) SnapShot: neuromodulation. Cell 155(482-482):e481

Burton SD, LaRocca G, Liu A, Cheetham CE, Urban NN (2017) Olfactory bulb deep short-axon cells mediate widespread inhibition of tufted cell apical dendrites. J Neurosci 37:1117-1138

Burton SD, Lepousez G, Lledo PM, Wachowiak M (2020) Neural circuits of the mammalian main olfactory bulb. In: Rubenstein J, Rakic P, Chen B, Kwan KY (eds) Neural Circuit and Cognitive Development. Academic Press, pp 3-26

Caillol M, Aioun J, Baly C, Persuy MA, Salesse R (2003) Localization of orexins and their receptors in the rat olfactory system: possible modulation of olfactory perception by a neuropeptide synthetized centrally or locally. Brain Res 960:48-61

Carlson KS, Whitney MS, Gadziola MA, Deneris ES, Wesson DW (2016). Preservation of essential odor-guided behaviors and odor-based reversal learning after targeting adult brain serotonin synthesis. eNeuro 3:

Carnes KM, Fuller TA, Price JL (1990) Sources of presumptive glutamatergic/aspartatergic afferents to the magnocellular basal forebrain in the rat. J Comp Neurol 302:824-852

Carson KA (1984) Quantitative localization of neurons projecting to the mouse main olfactory bulb. Brain Res Bull 12:629-634

Case DT, Burton SD, Gedeon JY, Williams SG, Urban NN, Seal RP (2017) Layer- and cell type-selective co-transmission by a basal forebrain cholinergic projection to the olfactory bulb. Nat Commun 8:652

Chandler DJ, Jensen P, McCall JG, Pickering AE, Schwarz LA, Totah NK (2019) Redefining noradrenergic neuromodulation of behavior: impacts of a modular locus coeruleus architecture. J Neurosci 39:8239-8249

Chapuis J, Cohen Y, He X, Zhang Z, Jin S, Xu F, Wilson DA (2013) Lateral entorhinal modulation of piriform cortical activity and fine odor discrimination. J Neurosci 33:13449-13459

Chaudhury D, Escanilla O, Linster C (2009) Bulbar acetylcholine enhances neural and perceptual odor discrimination. J Neurosci 29:52-60

Chelminski Y, Magnan C, Luquet SH, Everard A, Meunier N, Gurden H, Martin C (2017) Odor-induced neuronal rhythms in the olfactory bulb are profoundly modified in ob/ob obese mice. Front Physiol 8:2 
Ciombor KJ, Ennis M, Shipley MT (1999) Norepinephrine increases rat mitral cell excitatory responses to weak olfactory nerve input via alpha-1 receptors in vitro. Neuroscience 90:595-606

Cleland TA (2010) Early transformations in odor representation. Trends Neurosci 33:130-139

Cleland TA, Morse A, Yue EL, Linster C (2002) Behavioral models of odor similarity. Behav Neurosci 116:222-231

Corthell JT, Olcese J, Trombley PQ (2014) Melatonin in the mammalian olfactory bulb. Neuroscience 261:74-84

D'Souza RD, Parsa PV, Vijayaraghavan S (2013) Nicotinic receptors modulate olfactory bulb external tufted cells via an excitationdependent inhibitory mechanism. J Neurophysiol 110:1544-1553

D'Souza RD, Vijayaraghavan S (2012) Nicotinic receptor-mediated filtering of mitral cell responses to olfactory nerve inputs involves the $\alpha 3 \beta 4$ subtype. J Neurosci 32:3261-3266

D'Souza RD, Vijayaraghavan S (2014) Paying attention to smell: cholinergic signaling in the olfactory bulb. Front Synaptic Neurosci 6:21

Dahlstroem A, Fuxe K (1964) Evidence for the existence of monoaminecontaining neurons in the central nervous system. I. Demonstration of existence of monoamine-containing neurons in the central nervous system . Acta Physiol Scand Suppl SUPPL 232:231-255

Dana H, Sun Y, Mohar B, Hulse BK, Kerlin AM, Hasseman JP, Tsegaye G, Tsang A, Wong A, Patel R, Macklin JJ, Chen Y, Konnerth A, Jayaraman V, Looger LL, Schreiter ER, Svoboda K, Kim DS (2019) High-performance calcium sensors for imaging activity in neuronal populations and microcompartments. Nat Methods 16:649-657

Davis BJ, Macrides F (1981) The organization of centrifugal projections from the anterior olfactory nucleus, ventral hippocampal rudiment, and piriform cortex to the main olfactory bulb in the hamster: an autoradiographic study. J Comp Neurol 203:475-493

Davis BJ, Macrides F, Youngs WM, Schneider SP, Rosene DL (1978) Efferents and centrifugal afferents of the main and accessory olfactory bulbs in the hamster. Brain Res Bull 3:59-72

De Carlos JA, Lopez-Mascaraque L, Valverde F (1989) Connections of the olfactory bulb and nucleus olfactorius anterior in the hedgehog (Erinaceus europaeus): fluorescent tracers and HRP study. J Comp Neurol 279:601-618

De La Rosa-Prieto C, De Moya-Pinilla M, Saiz-Sanchez D, UbedaBanon I, Arzate DM, Flores-Cuadrado A, Liberia T, Crespo C, Martinez-Marcos A (2015) Olfactory and cortical projections to bulbar and hippocampal adult-born neurons. Front Neuroanat 9:4

Deshpande A, Bergami M, Ghanem A, Conzelmann KK, Lepier A, Gotz M, Berninger B (2013) Retrograde monosynaptic tracing reveals the temporal evolution of inputs onto new neurons in the adult dentate gyrus and olfactory bulb. Proc Natl Acad Sci U S A 110:E1152-1161

Devore S, Linster C (2012) Noradrenergic and cholinergic modulation of olfactory bulb sensory processing. Front Behav Neurosci 6:52

Dillon TS, Fox LC, Han C, Linster C (2013) 17beta-estradiol enhances memory duration in the main olfactory bulb in CD-1 mice. Behav Neurosci 127:923-931

Disney AA, Aoki C, Hawken MJ (2007) Gain Modulation by nicotine in Macaque V1. Neuron 56:701-713

Doetsch F, Caille I, Lim DA, Garcia-Verdugo JM, Alvarez-Buylla A (1999) Subventricular zone astrocytes are neural stem cells in the adult mammalian brain. Cell 97:703-716

Doty RL, Bagla R, Kim N (1999) Physostigmine enhances performance on an odor mixture discrimination test. Physiol Behav 65:801-804

Doucette W, Milder J, Restrepo D (2007) Adrenergic modulation of olfactory bulb circuitry affects odor discrimination. Learning \& Memory 14:539-547

Durand M, Coronas V, Jourdan F, Quirion R (1998) Developmental and aging aspects of the cholinergic innervation of the olfactory bulb. Int J Dev Neurosci 16:777-785
Eckmeier D, Shea SD (2014) Noradrenergic plasticity of olfactory sensory neuron inputs to the main olfactory bulb. J Neurosci 34:15234-15243

Economo MN, Hansen KR, Wachowiak M (2016) Control of mitral/ tufted cell output by selective inhibition among olfactory bulb glomeruli. Neuron 91:397-411

Escanilla O, Alperin S, Youssef M, Ennis M, Linster C (2012) Noradrenergic but not cholinergic modulation of olfactory bulb during processing of near threshold concentration stimuli. Behav Neurosci 126:720-728

Escanilla O, Arrellanos A, Karnow A, Ennis M, Linster C (2010) Noradrenergic modulation of behavioral odor detection and discrimination thresholds in the olfactory bulb. Eur J Neurosci 32:458-468

Esquivelzeta Rabell J, Mutlu K, Noutel J, Martin Del Olmo P, Haesler S (2017) Spontaneous rapid odor source localization behavior requires interhemispheric communication. Curr Biol 27(1542-1548):e1544

Fadool DA, Tucker K, Pedarzani P (2011). Mitral cells of the olfactory bulb perform metabolic sensing and are disrupted by obesity at the level of the Kv1.3 ion channel. PLoS One 6:e24921

Fadool DA, Tucker K, Phillips JJ, Simmen JA (2000) Brain insulin receptor causes activity-dependent current suppression in the olfactory bulb through multiple phosphorylation of Kv1.3. J Neurophysiol 83:2332-2348

Ferezou I, Bolea S, Petersen CC (2006) Visualizing the cortical representation of whisker touch: voltage-sensitive dye imaging in freely moving mice. Neuron 50:617-629

Ferguson JN, Young LJ, Hearn EF, Matzuk MM, Insel TR, Winslow JT (2000) Social amnesia in mice lacking the oxytocin gene. Nat Genet 25:284-288

Ferris CF, Yee JR, Kenkel WM, Dumais KM, Moore K, Veenema AH, Kulkarni P, Perkybile AM, Carter CS (2015) Distinct BOLD activation profiles following central and peripheral oxytocin administration in awake rats. Front Behav Neurosci 9:245

Filip M, Bader M (2009) Overview on 5-HT receptors and their role in physiology and pathology of the central nervous system. Pharmacological Reports 61:761-777

Freund-Mercier MJ, Stoeckel ME, Klein MJ (1994) Oxytocin receptors on oxytocin neurones: histoautoradiographic detection in the lactating rat. J Physiol 480(Pt 1):155-161

Fuxe K, Borroto-Escuela DO, Romero-Fernandez W, Diaz-Cabiale Z, Rivera A, Ferraro L, Tanganelli S, Tarakanov AO, Garriga P, Narvaez JA, Ciruela F, Guescini M, Agnati LF (2012). Extrasynaptic neurotransmission in the modulation of brain function. Focus on the striatal neuronal-glial networks. Front Physiol 3:136

Garcia-Gonzalez D, Khodosevich K, Watanabe Y, Rollenhagen A, Lubke JHR, Monyer H (2017) Serotonergic projections govern postnatal neuroblast migration. Neuron 94(534-549):e539

Gascuel J, Lemoine A, Rigault C, Datiche F, Benani A, Penicaud L, LopezMascaraque L (2012) Hypothalamus-olfactory system crosstalk: orexin a immunostaining in mice. Front Neuroanat 6:44

Gaudry Q (2018) Serotonergic modulation of olfaction in rodents and insects. Yale J Biol Med 91:23-32

Gaykema RP, Luiten PG, Nyakas C, Traber J (1990) Cortical projection patterns of the medial septum-diagonal band complex. J Comp Neurol 293:103-124

Genovese F, Bauersachs HG, Grasser I, Kupke J, Magin L, Daiber P, Nakajima J, Mohrlen F, Messlinger K, Frings S (2017) Possible role of calcitonin gene-related peptide in trigeminal modulation of glomerular microcircuits of the rodent olfactory bulb. Eur J Neurosci 45:587-600

Gervais R (1979) Unilateral lesions of the olfactory tubercle modifying general arousal effects in the rat olfactory bulb. Electroencephalogr Clin Neurophysiol 46:665-674

Getchell TV, Kwong K, Saunders CP, Stromberg AJ, Getchell ML (2006) Leptin regulates olfactory-mediated behavior in ob/ob mice. Physiol Behav 87:848-856 
Gheusi G, Cremer H, McLean H, Chazal G, Vincent JD, Lledo PM (2000) Importance of newly generated neurons in the adult olfactory bulb for odor discrimination. Proc Natl Acad Sci U S A 97:1823-1828

Gielow MR, Zaborszky L (2017) The input-output relationship of the cholinergic basal forebrain. Cell Rep 18:1817-1830

Glusman G, Yanai I, Rubin I, Lancet D (2001) The complete human olfactory subgenome. Genome Res 11:685-702

Goard M, Dan Y (2009) Basal forebrain activation enhances cortical coding of natural scenes. Nat Neurosci 12:1444-1449

Gomez C, Brinon JG, Barbado MV, Weruaga E, Valero J, Alonso JR (2005) Heterogeneous targeting of centrifugal inputs to the glomerular layer of the main olfactory bulb. J Chem Neuroanat 29:238-254

Gomez C, Brinon JG, Colado MI, Orio L, Vidal M, Barbado MV, Alonso JR (2006) Differential effects of unilateral olfactory deprivation on noradrenergic and cholinergic systems in the main olfactory bulb of the rat. Neuroscience 141:2117-2128

Gracia-Llanes FJ, Crespo C, Blasco-Ibáñez JM, Nacher J, Varea E, Rovira-Esteban L, Martínez-Guijarro FJ (2010) GABAergic basal forebrain afferents innervate selectively GABAergic targets in the main olfactory bulb. Neuroscience 170:913-922

Grandjean J, Corcoba A, Kahn MC, Upton AL, Deneris ES, Seifritz E, Helmchen F, Mann EO, Rudin M, Saab BJ (2019) A brain-wide functional map of the serotonergic responses to acute stress and fluoxetine. Nat Commun 10:350

Gritti I, Henny P, Galloni F, Mainville L, Mariotti M, Jones BE (2006) Stereological estimates of the basal forebrain cell population in the rat, including neurons containing choline acetyltransferase, glutamic acid decarboxylase or phosphate-activated glutaminase and colocalizing vesicular glutamate transporters. Neuroscience 143:1051-1064

Grobman M, Dalal T, Lavian H, Shmuel R, Belelovsky K, Xu F, Korngreen A, Haddad R (2018) A mirror-symmetric excitatory link coordinates odor maps across olfactory bulbs and enables odor perceptual unity. Neuron 99(800-813):e806

Grzanna R, Molliver ME (1980) The locus coeruleus in the rat: an immunohistochemical delineation. Neuroscience 5:21-40

Guerin D, Peace ST, Didier A, Linster C, Cleland TA (2008) Noradrenergic neuromodulation in the olfactory bulb modulates odor habituation and spontaneous discrimination. Behav Neurosci 122:816-826

Haberly LB (2001) Parallel-distributed processing in olfactory cortex: new insights from morphological and physiological analysis of neuronal circuitry. Chem Senses 26:551-576

Haberly LB, Price JL (1978) Association and commissural fiber systems of the olfactory cortex of the rat. J Comp Neurol 178:711-740

Halasz N, Shepherd GM (1983) Neurochemistry of the vertebrate olfactory bulb. Neuroscience 10:579-619

Hanson E, Swanson J, Arenkiel BR (2017). Sensory experience shapes the integration of adult-born neurons into the olfactory bulb. $\mathrm{J}$ Nat Sci 3:

Hanson E, Swanson J, Arenkiel BR (2020) GABAergic input from the basal forebrain promotes the survival of adult-born neurons in the mouse olfactory bulb. Front Neural Circuits 14:17

Hardy A, Palouzier-Paulignan B, Duchamp A, Royet JP, Duchamp-Viret P (2005) 5-Hydroxytryptamine action in the rat olfactory bulb: in vitro electrophysiological patch-clamp recordings of juxtaglomerular and mitral cells. Neuroscience 131:717-731

Hardy AB, Aioun J, Baly C, Julliard KA, Caillol M, Salesse R, Duchamp-Viret P (2005) Orexin A modulates mitral cell activity in the rat olfactory bulb: patch-clamp study on slices and immunocytochemical localization of orexin receptors. Endocrinology 146:4042-4053

Harvey JD, Heinbockel T (2018). Neuromodulation of synaptic transmission in the main olfactory bulb. Int $\mathrm{J}$ Environ Res Public Health 15:
Hayar A, Heyward PM, Heinbockel T, Shipley MT, Ennis M (2001) Direct excitation of mitral cells via activation of alpha1-noradrenergic receptors in rat olfactory bulb slices. J Neurophysiol 86:2173-2182

Heimer L (1968) Synaptic distribution of centripetal and centrifugal nerve fibres in the olfactory system of the rat. An experimental anatomical study. J Anat 103:413-432

Henny P, Jones BE (2008) Projections from basal forebrain to prefrontal cortex comprise cholinergic, GABAergic and glutamatergic inputs to pyramidal cells or interneurons. Eur J Neurosci 27:654-670

Henquin JC (2011) The dual control of insulin secretion by glucose involves triggering and amplifying pathways in beta-cells. Diabetes Res Clin Pract 93(Suppl 1):S27-31

Hill JM, Lesniak MA, Pert CB, Roth J (1986) Autoradiographic localization of insulin receptors in rat brain: prominence in olfactory and limbic areas. Neuroscience 17:1127-1138

Hoglinger GU, Alvarez-Fischer D, Arias-Carrion O, Djufri M, Windolph A, Keber U, Borta A, Ries V, Schwarting RK, Scheller D, Oertel WH (2015) A new dopaminergic nigro-olfactory projection. Acta Neuropathol 130:333-348

Hoglinger GU, Rizk P, Muriel MP, Duyckaerts C, Oertel WH, Caille I, Hirsch EC (2004) Dopamine depletion impairs precursor cell proliferation in Parkinson disease. Nat Neurosci 7:726-735

Horvath TL, Gao XB (2005) Input organization and plasticity of hypocretin neurons: possible clues to obesity's association with insomnia. Cell Metab 1:279-286

Hoyk Z, Csakvari E, Gyenes A, Siklos L, Harada N, Parducz A (2014) Aromatase and estrogen receptor beta expression in the rat olfactory bulb: Neuroestrogen action in the first relay station of the olfactory pathway? Acta Neurobiol Exp (Wars) 74:1-14

Hunt S, Schmidt J (1978) Some observations on the binding patterns of alpha-bungarotoxin in the central nervous system of the rat. Brain Res 157:213-232

Igarashi KM, Ieki N, An M, Yamaguchi Y, Nagayama S, Kobayakawa K, Kobayakawa R, Tanifuji M, Sakano H, Chen WR, Mori K (2012) Parallel mitral and tufted cell pathways route distinct odor information to different targets in the olfactory cortex. J Neurosci 32:7970-7985

Illig KR, Eudy JD (2009) Contralateral projections of the rat anterior olfactory nucleus. J Comp Neurol 512:115-123

In 't Zandt EE, Cansler HL, Denson HB, Wesson DW (2019) Centrifugal innervation of the olfactory bulb: a reappraisal. eNeuro 6

Irwin M, Greig A, Tvrdik P, Lucero MT (2015) PACAP modulation of calcium ion activity in developing granule cells of the neonatal mouse olfactory bulb. J Neurophysiol 113:1234-1248

Jacob SN, Nienborg H (2018) Monoaminergic neuromodulation of sensory processing. Front Neural Circuits 12:51

Jahr C, Nicoll R (1982) An intracellular analysis of dendrodendritic inhibition in the turtle in vitro olfactory bulb. J Physiol 326:213-234

Jr O'Hanlon JF (1965) Adrenaline and noradrenaline: relation to performance in a visual vigilance task. Science 150:507-509

Julliard AK, Al Koborssy D, Fadool DA, Palouzier-Paulignan B (2017) Nutrient sensing: another chemosensitivity of the olfactory system. Front Physiol 8:468

Julliard AK, Chaput MA, Apelbaum A, Aime P, Mahfouz M, DuchampViret $P$ (2007) Changes in rat olfactory detection performance induced by orexin and leptin mimicking fasting and satiation. Behav Brain Res 183:123-129

Kalen P, Wiklund L (1989) Projections from the medial septum and diagonal band of Broca to the dorsal and central superior raphe nuclei: a non-cholinergic pathway. Exp Brain Res 75:401-416

Kaneko N, Okano H, Sawamoto K (2006) Role of the cholinergic system in regulating survival of newborn neurons in the adult mouse dentate gyrus and olfactory bulb. Genes Cells 11:1145-1159 
Kapoor V, Provost AC, Agarwal P, Murthy VN (2016) Activation of raphe nuclei triggers rapid and distinct effects on parallel olfactory bulb output channels. Nat Neurosci 19:271-282

Kasa P, Hlavati I, Dobo E, Wolff A, Joo F, Wolff JR (1995) Synaptic and non-synaptic cholinergic innervation of the various types of neurons in the main olfactory bulb of adult rat: Immunocytochemistry of choline acetyltransferase. Neuroscience 67:667-677

Katz PS (1999) Beyond neurotransmission : neuromodulation and its importance for information processing. Oxford University Press, Osford, New York

Kay LM, Lancaster LR, Freeman WJ (1996) Reafference and attractors in the olfactory system during odor recognition. Int J Neural Syst 7:489-495

Keiger CJ, Walker JC (2000) Individual variation in the expression profiles of nicotinic receptors in the olfactory bulb and trigeminal ganglion and identification of alpha2, alpha6, alpha9, and beta3 transcripts. Biochem Pharmacol 59:233-240

Kikuta S, Sato K, Kashiwadani H, Tsunoda K, Yamasoba T, Mori K (2010) Neurons in the anterior olfactory nucleus pars externa detect right or left localization of odor sources. Proc Natl Acad Sci U S A 107:12363-12368

Knobloch HS, Charlet A, Hoffmann LC, Eliava M, Khrulev S, Cetin AH, Osten P, Schwarz MK, Seeburg PH, Stoop R, Grinevich V (2012) Evoked axonal oxytocin release in the central amygdala attenuates fear response. Neuron 73:553-566

Kojima M, Hosoda H, Date Y, Nakazato M, Matsuo H, Kangawa K (1999) Ghrelin is a growth-hormone-releasing acylated peptide from stomach. Nature 402:656-660

Kosaka T, Kosaka K (2016) Neuronal organization of the main olfactory bulb revisited. Anat Sci Int 91:115-127

Lazarini F, Mouthon MA, Gheusi G, de Chaumont F, Olivo-Marin JC, Lamarque S, Abrous DN, Boussin FD, Lledo PM (2009) Cellular and behavioral effects of cranial irradiation of the subventricular zone in adult mice. PLoS ONE 4:e7017

Le Jeune H, Aubert I, Jourdan F, Quirion R (1995) Comparative laminar distribution of various autoradiographic cholinergic markers in adult rat main olfactory bulb. J Chem Neuroanat 9:99-112

Lecoq J, Tiret P, Najac M, Shepherd GM, Greer CA, Charpak S (2009) Odor-evoked oxygen consumption by action potential and synaptic transmission in the olfactory bulb. J Neurosci 29:1424-1433

Lee C, Lavoie A, Liu J, Chen SX, Liu BH (2020) Light up the brain: the application of optogenetics in cell-type specific dissection of mouse brain circuits. Front Neural Circuits 14:18

Lei H, Mooney R, Katz LC (2006) Synaptic integration of olfactory information in mouse anterior olfactory nucleus. J Neurosci 26:12023-12032

Leitner FC, Melzer S, Lutcke H, Pinna R, Seeburg PH, Helmchen F, Monyer H (2016) Spatially segregated feedforward and feedback neurons support differential odor processing in the lateral entorhinal cortex. Nat Neurosci 19:935-944

Lepousez G, Nissant A, Bryant AK, Gheusi G, Greer CA, Lledo PM (2014) Olfactory learning promotes input-specific synaptic plasticity in adult-born neurons. Proc Natl Acad Sci U S A 111:13984-13989

Lepousez G, Valley MT, Lledo PM (2013) The impact of adult neurogenesis on olfactory bulb circuits and computations. Annu Rev Physiol 75:339-363

Levinson M, Kolenda JP, Alexandrou GJ, Escanilla O, Cleland TA, Smith DM, Linster C (2020) Context dependent odor learning requires the anterior olfactory nucleus. Behav Neurosci 134:332-343

Li A, Rao X, Zhou Y, Restrepo D (2020) Complex neural representation of odour information in the olfactory bulb. Acta Physiol (Oxf) 228:e13333

Li G, Cleland TA (2013) A two-layer biophysical model of cholinergic neuromodulation in olfactory bulb. J Neurosci 33:3037-3058
Li G, Linster C, Cleland TA (2015) Functional differentiation of cholinergic and noradrenergic modulation in a biophysical model of olfactory bulb granule cells. J Neurophysiol 114:3177-3200

Li X, Yu B, Sun Q, Zhang Y, Ren M, Zhang X, Li A, Yuan J, Madisen L, Luo Q, Zeng H, Gong H, Qiu Z (2018) Generation of a wholebrain atlas for the cholinergic system and mesoscopic projectome analysis of basal forebrain cholinergic neurons. Proc Natl Acad Sci U S A 115:415-420

Linster C, Kelsch W (2019). A computational model of oxytocin modulation of olfactory recognition memory. eNeuro 6:

Linster C, Midroit M, Forest J, Thenaisie Y, Cho C, Richard M, Didier A, Mandairon N (2020) Noradrenergic Activity in the Olfactory Bulb Is a Key Element for the Stability of Olfactory Memory. J Neurosci 40:9260-9271

Linster C, Nai Q, Ennis M (2011) Nonlinear effects of noradrenergic modulation of olfactory bulb function in adult rodents. J Neurophysiol 105:1432-1443

Liu S, Aungst JL, Puche AC, Shipley MT (2012) Serotonin modulates the population activity profile of olfactory bulb external tufted cells. J Neurophysiol 107:473-483

Liu S, Shao Z, Puche A, Wachowiak M, Rothermel M, Shipley MT (2015) Muscarinic receptors modulate dendrodendritic inhibitory synapses to sculpt glomerular output. J Neurosci 35:5680-5692

Liu Y, Jiang Y, Si Y, Kim JY, Chen ZF, Rao Y (2011) Molecular regulation of sexual preference revealed by genetic studies of 5-HT in the brains of male mice. Nature 472:95-99

Livneh Y, Adam Y, Mizrahi A (2014) Odor Processing by adult-born neurons. Neuron 81:1097-1110

Lizbinski KM, Dacks AM (2017) Intrinsic and extrinsic neuromodulation of olfactory processing. Front Cell Neurosci 11:424

Lledo PM, Alonso M, Grubb MS (2006) Adult neurogenesis and functional plasticity in neuronal circuits. Nat Rev Neurosci 7:179-193

Lledo PM, Valley M (2016). Adult Olfactory Bulb Neurogenesis. Cold Spring Harb Perspect Biol 8

Lois C, Alvarez-Buylla A (1994) Long-distance neuronal migration in the adult mammalian brain. Science 264:1145-1148

Luiten PG, Gaykema RP, Traber J, Spencer DG Jr (1987) Cortical projection patterns of magnocellular basal nucleus subdivisions as revealed by anterogradely transported Phaseolus vulgaris leucoagglutinin. Brain Res 413:229-250

Lukas M, Suyama H, Egger V (2019). Vasopressin cells in the rodent olfactory bulb resemble non-bursting superficial tufted cells and are primarily inhibited upon olfactory nerve stimulation. eNeuro 6

Luskin MB, Price JL (1983) The topographic organization of associational fibers of the olfactory system in the rat, including centrifugal fibers to the olfactory bulb. J Comp Neurol 216:264-291

Ma M, Luo M (2012) Optogenetic activation of basal forebrain cholinergic neurons modulates neuronal excitability and sensory responses in the main olfactory bulb. J Neurosci 32:10105-10116

Macrides F, Davis BJ, Youngs WM, Nadi NS, Margolis FL (1981) Cholinergic and catecholaminergic afferents to the olfactory bulb in the hamster: a neuroanatomical, biochemical, and histochemical investigation. J Comp Neurol 203:495-514

Mandairon N, Ferretti CJ, Stack CM, Rubin DB, Cleland TA, Linster C (2006) Cholinergic modulation in the olfactory bulb influences spontaneous olfactory discrimination in adult rats. Eur J Neurosci 24:3234-3244

Mandairon N, Peace S, Karnow A, Kim J, Ennis M, Linster C (2008) Noradrenergic modulation in the olfactory bulb influences spontaneous and reward-motivated discrimination, but not the formation of habituation memory. Eur J Neurosci 27:1210-1219

Manella LC, Petersen N, Linster C (2017) Stimulation of the locus ceruleus modulates signal-to-noise ratio in the olfactory bulb. $\mathrm{J}$ Neurosci 37:11605-11615 
Markopoulos F, Rokni D, Gire DH, Murthy VN (2012) Functional properties of cortical feedback projections to the olfactory bulb. Neuron 76:1175-1188

Maruska KP, Fernald RD (2010) Reproductive status regulates expression of sex steroid and GnRH receptors in the olfactory bulb. Behav Brain Res 213:208-217

Matsutani S, Yamamoto N (2008) Centrifugal innervation of the mammalian olfactory bulb. Anat Sci Int 83:218-227

Mazo C, Lepousez G, Nissant A, Valley MT, Lledo PM (2016) GABA(B) Receptors tune cortical feedback to the olfactory bulb. J Neurosci 36:8289-8304

McBurney-Lin J, Lu J, Zuo Y, Yang H (2019) Locus coeruleusnorepinephrine modulation of sensory processing and perception: a focused review. Neurosci Biobehav Rev 105:190-199

McEwen BS, Milner TA (2017) Understanding the broad influence of sex hormones and sex differences in the brain. J Neurosci Res 95:24-39

McIntyre JC, Thiebaud N, McGann JP, Komiyama T, Rothermel M (2017) Neuromodulation in Chemosensory Pathways. Chem Senses 42:375-379

McLean JH, Shipley MT, Nickell WT, Aston-Jones G, Reyher CK (1989) Chemoanatomical organization of the noradrenergic input from locus coeruleus to the olfactory bulb of the adult rat. J Comp Neurol 285:339-349

McLennan H (1971) The pharmacology of inhibition of mitral cells in the olfactory bulb. Brain Res 29:177-184

Mechawar N, Saghatelyan A, Grailhe R, Scoriels L, Gheusi G, Gabellec MM, Lledo PM, Changeux JP (2004) Nicotinic receptors regulate the survival of newborn neurons in the adult olfactory bulb. Proc Natl Acad Sci U S A 101:9822-9826

Medinaceli Quintela R, Bauer J, Wallhorn L, Le K, Brunert D, Rothermel M (2020) Dynamic Impairment of Olfactory Behavior and Signaling Mediated by an Olfactory Corticofugal System. J Neurosci 40:7269-7285

Merkle FT, Mirzadeh Z, Alvarez-Buylla A (2007) Mosaic organization of neural stem cells in the adult brain. Science 317:381-384

Miller JE, Granados-Fuentes D, Wang T, Marpegan L, Holy TE, Herzog ED (2014) Vasoactive intestinal polypeptide mediates circadian rhythms in mammalian olfactory bulb and olfaction. $\mathbf{J}$ Neurosci 34:6040-6046

Miranda-Martinez A, Mercado-Gomez OF, Arriaga-Avila V, GuevaraGuzman R (2017) Distribution of adiponectin receptors 1 and 2 in the rat olfactory bulb and the effect of adiponectin injection on insulin receptor expression. Int J Endocrinol 2017:4892609

Moberly AH, Schreck M, Bhattarai JP, Zweifel LS, Luo W, Ma M (2018) Olfactory inputs modulate respiration-related rhythmic activity in the prefrontal cortex and freezing behavior. Nat Commun 9:1528

Mombaerts P, Wang F, Dulac C, Chao SK, Nemes A, Mendelsohn M, Edmondson J, Axel R (1996) Visualizing an olfactory sensory map. Cell 87:675-686

Mouly AM, Elaagouby A, Ravel N (1995) A study of the effects of noradrenaline in the rat olfactory bulb using evoked field potential response. Brain Res 681:47-57

Mouret A, Lepousez G, Gras J, Gabellec MM, Lledo PM (2009) Turnover of newborn olfactory bulb neurons optimizes olfaction. J Neurosci 29:12302-12314

Muzerelle A, Scotto-Lomassese S, Bernard JF, Soiza-Reilly M, Gaspar $\mathrm{P}$ (2016) Conditional anterograde tracing reveals distinct targeting of individual serotonin cell groups (B5-B9) to the forebrain and brainstem. Brain Struct Funct 221:535-561

Nadim F, Bucher D (2014) Neuromodulation of neurons and synapses. Curr Opin Neurobiol 29:48-56

Nagayama S, Enerva A, Fletcher ML, Masurkar AV, Igarashi KM, Mori K, Chen WR (2010) Differential Axonal Projection of Mitral and
Tufted Cells in the Mouse Main Olfactory System. Frontiers in Neural Circuits 4

Nagayama S, Homma R, Imamura F (2014) Neuronal organization of olfactory bulb circuits. Front Neural Circuits 8:98

Nai Q, Dong HW, Hayar A, Linster C, Ennis M (2009) Noradrenergic regulation of GABAergic inhibition of main olfactory bulb mitral cells varies as a function of concentration and receptor subtype. J Neurophysiol 101:2472-2484

Nai Q, Dong HW, Linster C, Ennis M (2010) Activation of alpha1 and alpha2 noradrenergic receptors exert opposing effects on excitability of main olfactory bulb granule cells. Neurosci 169:882-892

Nei M, Niimura Y, Nozawa M (2008) The evolution of animal chemosensory receptor gene repertoires: roles of chance and necessity. Nat Rev Genet 9:951-963

Neville KR, Haberly LB (2004) Olfactory cortex. The synaptic organization of the brain $5: 415-454$

Nickell WT, Shipley MT (1988) Neurophysiology of magnocellular forebrain inputs to the olfactory bulb in the rat: frequency potentiation of field potentials and inhibition of output neurons. J Neurosci 8:4492-4502

Nissant A, Bardy C, Katagiri H, Murray K, Lledo PM (2009) Adult neurogenesis promotes synaptic plasticity in the olfactory bulb. Nat Neurosci 12:728-730

Nocera S, Simon A, Fiquet O, Chen Y, Gascuel J, Datiche F, Schneider N, Epelbaum J, Viollet C (2019) Somatostatin serves a modulatory role in the mouse olfactory bulb: neuroanatomical and behavioral evidence. Front Behav Neurosci 13:61

Nunez-Parra A, Maurer RK, Krahe K, Smith RS, Araneda RC (2013) Disruption of centrifugal inhibition to olfactory bulb granule cells impairs olfactory discrimination. Proc Natl Acad Sci U S A 110:14777-14782

Oettl LL, Ravi N, Schneider M, Scheller MF, Schneider P, Mitre M, da Silva GM, Froemke RC, Chao MV, Young WS, Meyer-Lindenberg A, Grinevich V, Shusterman R, Kelsch W (2016) Oxytocin enhances social recognition by modulating cortical control of early olfactory processing. Neuron 90:609-621

Okaty BW, Commons KG, Dymecki SM (2019) Embracing diversity in the 5-HT neuronal system. Nat Rev Neurosci 20:397-424

Okutani F, Kaba H, Takahashi S, Seto K (1998) The biphasic effects of locus coeruleus noradrenergic activation on dendrodendritic inhibition in the rat olfactory bulb. Brain Res 783:272-279

Otazu GH, Chae H, Davis MB, Albeanu DF (2015) Cortical feedback decorrelates olfactory bulb output in awake mice. Neuron 86:1461-1477

Padmanabhan K, Osakada F, Tarabrina A, Kizer E, Callaway EM, Gage FH, Sejnowski TJ (2016) Diverse Representations of olfactory information in centrifugal feedback projections. J Neurosci 36:7535-7545

Padmanabhan K, Osakada F, Tarabrina A, Kizer E, Callaway EM, Gage FH, Sejnowski TJ (2018) Centrifugal inputs to the main olfactory bulb revealed through whole brain circuit-mapping. Front Neuroanat 12:115

Paez-Gonzalez P, Asrican B, Rodriguez E, Kuo CT (2014) Identification of distinct ChAT(+) neurons and activity-dependent control of postnatal SVZ neurogenesis. Nat Neurosci 17:934-942

Palouzier-Paulignan B, Lacroix MC, Aime P, Baly C, Caillol M, Congar P, Julliard AK, Tucker K, Fadool DA (2012) Olfaction under metabolic influences. Chem Senses 37:769-797

Pandipati S, Gire DH, Schoppa NE (2010) Adrenergic receptor-mediated disinhibition of mitral cells triggers long-term enhancement of synchronized oscillations in the olfactory bulb. J Neurophysiol 104:665-674

Parikh V, Sarter M (2008) Cholinergic mediation of attention: contributions of phasic and tonic increases in prefrontal cholinergic activity. Ann N Y Acad Sci 1129:225-235 
Parsa PV, D’Souza RD, Vijayaraghavan S (2015) Signaling between periglomerular cells reveals a bimodal role for GABA in modulating glomerular microcircuitry in the olfactory bulb. Proc Natl Acad Sci U S A 112:9478-9483

Paul A, Chaker Z, Doetsch F (2017) Hypothalamic regulation of regionally distinct adult neural stem cells and neurogenesis. Science 356:1383-1386

Perez H, Hernandez A, Almli CR (1987) Locus coeruleus stimulation modulates olfactory bulb evoked potentials. Brain Res Bull 18:767-770

Petreanu L, Alvarez-Buylla A (2002) Maturation and death of adultborn olfactory bulb granule neurons: role of olfaction. J Neurosci 22:6106-6113

Petzold GC, Hagiwara A, Murthy VN (2009) Serotonergic modulation of odor input to the mammalian olfactory bulb. Nat Neurosci 12:784-791

Peyron C, Tighe DK, van den Pol AN, de Lecea L, Heller HC, Sutcliffe JG, Kilduff TS (1998) Neurons containing hypocretin (orexin) project to multiple neuronal systems. J Neurosci 18:9996-10015

Picciotto MR, Higley MJ, Mineur YS (2012) Acetylcholine as a neuromodulator: cholinergic signaling shapes nervous system function and behavior. Neuron 76:116-129

Pinching AJ, Powell TPS (1972) Termination of centrifugal fibers in glomerular layer of olfactory bulb. J Cell Sci 10:621-630

Plummer NW, Chandler DJ, Powell JM, Scappini EL, Waterhouse BD, Jensen P (2020) An Intersectional Viral-Genetic Method for Fluorescent Tracing of Axon Collaterals Reveals Details of Noradrenergic Locus Coeruleus Structure. eNeuro 7

Pouille F, Schoppa NE (2018) Cannabinoid receptors modulate excitation of an olfactory bulb local circuit by cortical feedback. Front Cell Neurosci 12:47

Pressler RT, Inoue T, Strowbridge BW (2007) Muscarinic receptor activation modulates granule cell excitability and potentiates inhibition onto mitral cells in the rat olfactory bulb. J Neurosci 27:10969-10981

Price JL, Powell TP (1970) An experimental study of the origin and the course of the centrifugal fibres to the olfactory bulb in the rat. J Anat 107:215-237

Ramirez-Gordillo D, Ma M, Restrepo D (2018) Precision of classification of odorant value by the power of olfactory bulb oscillations is altered by optogenetic silencing of local adrenergic innervation. Front Cell Neurosci 12:48

Ravel N, Elaagouby A, Gervais R (1994) Scopolamine injection into the olfactory bulb impairs short-term olfactory memory in rats. Behav Neurosci 108:317-324

Ressler KJ, Sullivan SL, Buck LB (1994) Information coding in the olfactory system: evidence for a stereotyped and highly organized map in the olfactory bulb. Cell 79:1245-1255

Reyher CK, Schwerdtfeger WK, Baumgarten HG (1988) Interbulbar axonal collateralization and morphology of anterior olfactory nucleus neurons in the rat. Brain Res Bull 20:549-566

Reynolds JH, Chelazzi L (2004) Attentional modulation of visual processing. Annu Rev Neurosci 27:611-647

Rhea EM, Salameh TS, Gray S, Niu J, Banks WA, Tong J (2018) Ghrelin transport across the blood-brain barrier can occur independently of the growth hormone secretagogue receptor. Mol Metab 18:88-96

Rikani AA, Choudhry Z, Choudhry AM, Zenonos G, Tariq S, Mobassarah NJ (2013) Spatially regulated adult neurogenesis Ann Neurosci 20:67-70

Ross JM, Bendahmane M, Fletcher ML (2019) Olfactory Bulb Muscarinic Acetylcholine Type 1 Receptors Are Required for Acquisition of Olfactory Fear Learning. Front Behav Neurosci 13:164

Rothermel M, Carey RM, Puche A, Shipley MT, Wachowiak M (2014) Cholinergic inputs from basal forebrain add an excitatory bias to odor coding in the olfactory bulb. J Neurosci 34:4654-4664
Rothermel M, Wachowiak M (2014) Functional imaging of cortical feedback projections to the olfactory bulb. Front Neural Circuits $8: 73$

Sakurai T, Amemiya A, Ishii M, Matsuzaki I, Chemelli RM, Tanaka H, Williams SC, Richardson JA, Kozlowski GP, Wilson S, Arch JR, Buckingham RE, Haynes AC, Carr SA, Annan RS, McNulty DE, Liu WS, Terrett JA, Elshourbagy NA, Bergsma DJ, Yanagisawa M (1998) Orexins and orexin receptors: a family of hypothalamic neuropeptides and $\mathrm{G}$ protein-coupled receptors that regulate feeding behavior. Cell 92:573-585

Sakurai T, Mieda M, Tsujino N (2010) The orexin system: roles in sleep/wake regulation. Ann N Y Acad Sci 1200:149-161

Salcedo E, Tran T, Ly X, Lopez R, Barbica C, Restrepo D, Vijayaraghavan S (2011) Activity-dependent changes in cholinergic innervation of the mouse olfactory bulb. PLoS ONE 6:e25441

Salmoiraghi GC, Bloom FE, Costa E (1964) Adrenergic mechanisms in rabbit olfactory bulb. Am J Physiol 207:1417-1424

Salomon RM, Cowan RL (2013) Oscillatory serotonin function in depression. Synapse 67:801-820

Sanz Diez A, Najac M, De Saint JD (2019) Basal forebrain GABAergic innervation of olfactory bulb periglomerular interneurons. J Physiol 597:2547-2563

Sara SJ (2009) The locus coeruleus and noradrenergic modulation of cognition. Nat Rev Neurosci 10:211-223

Sara SJ, Bouret S (2012) Orienting and reorienting: the locus coeruleus mediates cognition through arousal. Neuron 76:130-141

Sarter M, Hasselmo ME, Bruno JP, Givens B (2005) Unraveling the attentional functions of cortical cholinergic inputs: interactions between signal-driven and cognitive modulation of signal detection. Brain Res Rev 48:98-111

Sayin S, Boehm AC, Kobler JM, De Backer JF, Grunwald Kadow IC (2018) Internal state dependent odor processing and perception-the role of neuromodulation in the fly olfactory system. Front Cell Neurosci 12:11

Scherer PE, Williams S, Fogliano M, Baldini G, Lodish HF (1995) A novel serum protein similar to $\mathrm{C} 1 \mathrm{q}$, produced exclusively in adipocytes. J Biol Chem 270:26746-26749

Schilit Nitenson A, Manzano Nieves G, Poeta DL, Bahar R, Rachofsky C, Mandairon N, Bath KG (2019) Acetylcholine regulates olfactory perceptual learning through effects on adult neurogenesis. iScience 22:544-556

Schmidt LJ, Strowbridge BW (2014) Modulation of olfactory bulb network activity by serotonin: synchronous inhibition of mitral cells mediated by spatially localized GABAergic microcircuits. Learn Mem 21:406-416

Schneider NY, Chaudy S, Epstein AL, Viollet C, Benani A, Penicaud L, Grosmaitre X, Datiche F, Gascuel J (2020) Centrifugal projections to the main olfactory bulb revealed by transsynaptic retrograde tracing in mice. J Comp Neurol 528:1805-1819

Schoenfeld TA, Macrides F (1984) Topographic organization of connections between the main olfactory bulb and pars externa of the anterior olfactory nucleus in the hamster. J Comp Neurol 227:121-135

Schwarz LA, Miyamichi K, Gao XJ, Beier KT, Weissbourd B, DeLoach KE, Ren J, Ibanes S, Malenka RC, Kremer EJ, Luo L (2015) Viral-genetic tracing of the input-output organization of a central noradrenaline circuit. Nature 524:88-92

Shafa F, Meisami E (1977) A horseradish peroxidase study of the origin of central projections to the rat olfaction bulb. Brain Res 136:355-359

Sharma G (2013) The dominant functional nicotinic receptor in progenitor cells in the rostral migratory stream is the alpha3beta4 subtype. J Neurophysiol 109:867-872

Shepherd GM (1972) Synaptic organization of the mammalian olfactory bulb. Physiol Rev 52:864-917 
Shepherd GM, Chen WR, Greer CA (2004) Olfactory bulb. The Synaptic Organization of the Brain, pp 165-216

Shingo T, Gregg C, Enwere E, Fujikawa H, Hassam R, Geary C, Cross JC, Weiss S (2003) Pregnancy-stimulated neurogenesis in the adult female forebrain mediated by prolactin. Science 299:117-120

Shioda S, Funahashi H, Nakajo S, Yada T, Maruta O, Nakai Y (1998) Immunohistochemical localization of leptin receptor in the rat brain. Neurosci Lett 243:41-44

Shipley MT, Adamek GD (1984) The connections of the mouse olfactory bulb: a study using orthograde and retrograde transport of wheat germ agglutinin conjugated to horseradish peroxidase. Brain Res Bull 12:669-688

Short SM, Wachowiak M (2019) Temporal Dynamics of InhalationLinked Activity across Defined Subpopulations of Mouse Olfactory Bulb Neurons Imaged In Vivo. eNeuro 6:

Sicard G, Holley A (1984) Receptor cell responses to odorants: similarities and differences among odorants. Brain Res 292:283-296

Smith RS, Araneda RC (2010) Cholinergic modulation of neuronal excitability in the accessory olfactory bulb. J Neurophysiol 104:2963-2974

Soria-Gomez E, Bellocchio L, Reguero L, Lepousez G, Martin C, Bendahmane M, Ruehle S, Remmers F, Desprez T, Matias I, Wiesner T, Cannich A, Nissant A, Wadleigh A, Pape HC, Chiarlone AP, Quarta C, Verrier D, Vincent P, Massa F, Lutz B, Guzman M, Gurden H, Ferreira G, Lledo PM, Grandes P, Marsicano G (2014) The endocannabinoid system controls food intake via olfactory processes. Nat Neurosci 17:407-415

Staubli U, Ivy G, Lynch G (1984) Hippocampal denervation causes rapid forgetting of olfactory information in rats. Proc Natl Acad Sci U S A 81:5885-5887

Steinfeld R, Herb JT, Sprengel R, Schaefer AT, Fukunaga I (2015) Divergent innervation of the olfactory bulb by distinct raphe nuclei. J Comp Neurol 523:805-813

Steward O, Scoville SA (1976) Cells of origin of entorhinal cortical afferents to the hippocampus and fascia dentata of the rat. J Comp Neurol 169:347-370

Strowbridge BW (2009) Role of cortical feedback in regulating inhibitory microcircuits. Ann N Y Acad Sci 1170:270-274

Sultan S, Mandairon N, Kermen F, Garcia S, Sacquet J, Didier A (2010) Learning-dependent neurogenesis in the olfactory bulb determines long-term olfactory memory. FASEB J 24:2355-2363

Sun C, Tang K, Wu J, Xu H, Zhang W, Cao T, Zhou Y, Yu T, Li A (2019) Leptin modulates olfactory discrimination and neural activity in the olfactory bulb. Acta Physiol (Oxf) 227:e13319

Suzuki Y, Kiyokage E, Sohn J, Hioki H, Toida K (2015) Structural basis for serotonergic regulation of neural circuits in the mouse olfactory bulb. J Comp Neurol 523:262-280

Takahashi H, Yoshihara S, Tsuboi A (2018) The functional role of olfactory bulb granule cell subtypes derived from embryonic and postnatal neurogenesis. Front Mol Neurosci 11:229

Thiebaud N, Gribble F, Reimann F, Trapp S, Fadool DA (2019) A unique olfactory bulb microcircuit driven by neurons expressing the precursor to glucagon-like peptide 1. Sci Rep 9:15542

Tong J, Mannea E, Aime P, Pfluger PT, Yi CX, Castaneda TR, Davis HW, Ren X, Pixley S, Benoit S, Julliard K, Woods SC, Horvath TL, Sleeman MM, D’Alessio D, Obici S, Frank R, Tschop MH (2011) Ghrelin enhances olfactory sensitivity and exploratory sniffing in rodents and humans. J Neurosci 31:5841-5846

Uematsu A, Tan BZ, Ycu EA, Cuevas JS, Koivumaa J, Junyent F, Kremer EJ, Witten IB, Deisseroth K, Johansen JP (2017) Modular organization of the brainstem noradrenaline system coordinates opposing learning states. Nat Neurosci 20:1602-1611

Ueno M, Dobrogowska DH, Vorbrodt AW (1996) Immunocytochemical evaluation of the blood-brain barrier to endogenous albumin in the olfactory bulb and pons of senescence-accelerated mice (SAM). Histochem Cell Biol 105:203-212

Vaccari C, Lolait SJ, Ostrowski NL (1998) Comparative distribution of vasopressin $\mathrm{V} 1 \mathrm{~b}$ and oxytocin receptor messenger ribonucleic acids in brain. Endocrinology 139:5015-5033

Vasquez-Lopez SA, Turcotte R, Koren V, Ploschner M, Padamsey Z, Booth MJ, Cizmar T, Emptage NJ (2018) Subcellular spatial resolution achieved for deep-brain imaging in vivo using a minimally invasive multimode fiber. Light Sci Appl 7:110

Vinograd A, Tasaka GI, Kreines L, Weiss Y, Mizrahi A (2019) The pre-synaptic landscape of mitral/tufted cells of the main olfactory bulb. Front Neuroanat 13:58

Wachowiak M, Shipley MT (2006) Coding and synaptic processing of sensory information in the glomerular layer of the olfactory bulb. Semin Cell Dev Biol 17:411-423

Wacker DW, Engelmann M, Tobin VA, Meddle SL, Ludwig M (2011) Vasopressin and social odor processing in the olfactory bulb and anterior olfactory nucleus. Ann N Y Acad Sci 1220:106-116

Wang CY, Liu Z, Ng YH, Sudhof TC (2020) A Synaptic Circuit Required for Acquisition but Not Recall of Social Transmission of Food Preference. Neuron 107(144-157):e144

Wang HL, Zhang S, Qi J, Wang H, Cachope R, Mejias-Aponte CA, Gomez JA, Mateo-Semidey GE, Beaudoin GMJ, Paladini CA, Cheer JF, Morales M (2019) Dorsal raphe dual serotoninglutamate neurons drive reward by establishing excitatory synapses on VTA mesoaccumbens dopamine neurons. Cell Rep 26(1128-1142):e1127

Waterhouse BD, Navarra RL (2019) The locus coeruleus-norepinephrine system and sensory signal processing: A historical review and current perspectives. Brain Res 1709:1-15

Wen P, Rao X, Xu L, Zhang Z, Jia F, He X, Xu F (2019) Cortical Organization of Centrifugal Afferents to the Olfactory Bulb: Mono- and Trans-synaptic Tracing with Recombinant Neurotropic Viral Tracers. Neurosci Bull 35:709-723

Weselek G, Keiner S, Fauser M, Wagenfuhr L, Muller J, Kaltschmidt B, Brandt MD, Gerlach M, Redecker C, Hermann A, Storch A (2020) Norepinephrine is a negative regulator of the adult periventricular neural stem cell niche. Stem Cells 38:1188-1201

Wesson DW (2020) The Tubular Striatum. J Neurosci 40:7379-7386

Wilson DA, Sullivan RM (2011) Cortical processing of odor objects. Neuron 72:506-519

Wilson DA, Xu W, Sadrian B, Courtiol E, Cohen Y, Barnes DC (2014) Cortical odor processing in health and disease. Prog Brain Res 208:275-305

$\mathrm{Xu} \mathrm{W}$, Wilson DA (2012) Odor-evoked activity in the mouse lateral entorhinal cortex. Neurosci 223:12-20

Yan Z, Tan J, Qin C, Lu Y, Ding C, Luo M (2008) Precise circuitry links bilaterally symmetric olfactory maps. Neuron 58:613-624

Yang C, Thankachan S, McCarley RW, Brown RE (2017) The menagerie of the basal forebrain: how many (neural) species are there, what do they look like, how do they behave and who talks to whom? Curr Opin Neurobiol 44:159-166

Yu GZ, Kaba H, Okutani F, Takahashi S, Higuchi T (1996) The olfactory bulb: a critical site of action for oxytocin in the induction of maternal behaviour in the rat. Neurosci 72:1083-1088

Yu GZ, Kaba H, Okutani F, Takahashi S, Higuchi T, Seto K (1996) The action of oxytocin originating in the hypothalamic paraventricular nucleus on mitral and granule cells in the rat main olfactory bulb. Neurosci 72:1073-1082

Zaborszky L, Carlsen J, Brashear HR, Heimer L (1986) Cholinergic and GABAergic afferents to the olfactory bulb in the rat with special emphasis on the projection neurons in the nucleus of the horizontal limb of the diagonal band. J Comp Neurol 243:488-509

Zaborszky L, Csordas A, Mosca K, Kim J, Gielow MR, Vadasz C, Nadasdy Z (2015) Neurons in the basal forebrain project to the cortex in a complex topographic organization that reflects corticocortical 
connectivity patterns: an experimental study based on retrograde tracing and 3D reconstruction. Cereb Cortex 25:118-137

Zaborszky L, Van den Pol AN, Gyengesi E (2012) The basal forebrain cholinergic projection system in mice. In: Watson C, Paxinos G, Puelles L (eds) The Mouse Nervous System. Elsevier, Amsterdam, pp 684-718

Zelano C, Sobel N (2005) Humans as an animal model for systemslevel organization of olfaction. Neuron 48:431-454

Zhang S, Xiao Q, Le W (2015) Olfactory dysfunction and neurotransmitter disturbance in olfactory bulb of transgenic mice expressing human A53T mutant alpha-synuclein. PLoS ONE 10:e0119928

Zhang Z, Zhang H, Wen P, Zhu X, Wang L, Liu Q, Wang J, He X, Wang H, Xu F (2017) Whole-brain mapping of the inputs and outputs of the medial part of the olfactory tubercle. Front Neural Circuits 11:52

Zhou FW, Dong HW, Ennis M (2016) Activation of beta-noradrenergic receptors enhances rhythmic bursting in mouse olfactory bulb external tufted cells. J Neurophysiol 116:2604-2614

Zhou FW, Puche AC, Shipley MT (2018) Short-Term Plasticity at Olfactory Cortex to Granule Cell Synapses Requires CaV2.1 Activation. Front Cell Neurosci 12:387

Zimnik NC, Treadway T, Smith RS, Araneda RC (2013) alpha(1A)Adrenergic regulation of inhibition in the olfactory bulb. J Physiol 591:1631-1643 